\title{
The entrepreneurial financing of the immigrant entrepreneurs: a literature review
}

\author{
Bryan Malki $(\mathbb{D} \cdot$ Timur Uman • Daniel Pittino
}

Accepted: 1 December 2020 / Published online: 21 December 2020

(C) The Author(s) 2020

\begin{abstract}
There is an increasing interest in the phenomenon of immigrant entrepreneurship. Despite the growing number of studies, the financing aspect of immigrant entrepreneurship is still an emergent subject. In this paper, we critically and systematically review the field of the entrepreneurial financing of immigrant entrepreneurs. For this purpose, we conduct a two-step analysis of 37 systematically selected articles. In the first step, we provide an overall description of the field, while in the second step we perform a SWOT analysis on different aspects of the field, including the units of analysis, the main questions, and the use of theories and methods in the field. The review identifies gaps and weaknesses in the field, suggests potential opportunities for future research, and highlights some threats that could impede the implementation of future opportunities. Finally, the review suggests further questions to be explored for future advancement of knowledge in the field.
\end{abstract}

Keywords Immigrant entrepreneurship . Entrepreneurial financing $\cdot$ Systematic review $\cdot$ SWOT analysis

JEL Classifications $\mathrm{J} 15 \cdot \mathrm{M} 13 \cdot \mathrm{L} 26 \cdot \mathrm{G} 20$

B. Malki $(\bowtie) \cdot$ T. Uman $\cdot$ D. Pittino Jönköping International Business School, Jönköping University, Gjuterigatan 5, 55111 Jönköping, Sweden e-mail: bryan.malki@ju.se

\section{Introduction}

The past two decades have witnessed an extraordinary increase in global migration flows. The proportion of the population born in a different country is above $10 \%$ in France and the UK, above $15 \%$ in Germany and the USA, and above $20 \%$ in Canada and Australia (Borjas 2014; Peri 2016; Rapoport and Toubal 2019). The economic implications of this phenomenon are attracting the attention of policymakers and scholars from different disciplines. In particular, recent studies have highlighted that immigrants' entrepreneurship is an important factor affecting growth and development in the host countries (e.g., Hunt and Gauthier-Loiselle 2010; Jones et al. 2019; Kahn et al. 2017; S. P. Kerr et al. 2015; Rodríguez-Pose and Von Berlepsch 2014).

Immigrant entrepreneurship can be defined as the process whereby immigrants (i.e., individuals born in a given country, who subsequently moved to a different country at some point in their lifetime) identify, create, and exploit economic opportunities to start new ventures in their country of destination (Dheer 2018). Immigrants exhibit a consistently high tendency to initiate self-employment in the hosting countries (e.g., Bates 1997; Sanders and Nee 1996). In the USA, for instance, highly skilled immigrants were observed to be more likely to initiate new ventures compared to their native peers (e.g., Fairlie and Lofstrom 2015; Hunt 2011, 2015). These entrepreneurial endeavors are driven by contrasting motivations. On the one hand, it has been found that immigrants are pushed into entrepreneurship as a response to the different obstacles that limit their participation in the labor market in the hosting 
countries, for instance, the lack of recognition of credentials, language deficiency, and racial and ethnic prejudices (e.g., Assudani 2009; Borjas 1986; K. Clark and Drinkwater 2000; Light and Rosenstein 1995; Vinogradov 2008). On the other hand, a significant proportion of pull entrepreneurship has also been observed among immigrants, as they are driven by the ambition to explore the potential of the mainstream market (e.g., Abada et al. 2014; Achidi Ndofor and Priem 2011; Chrysostome 2010).

Immigrant entrepreneurship is related to but distinct from similar categories investigated by researchers, such as ethnic/minority entrepreneurship (e.g., Bates et al. 2018; Bewaji et al. 2015; Freeland and Keister 2016). The membership of an ethnic or minority group can certainly be a component of the entrepreneurial process of immigrants; however, ethnicity and ethnic connections are neither necessary nor exclusive attributes of the immigrants' ventures (Cederberg and Villares-Varela 2019; Drori et al. 2009). In this sense, the perspective of immigrant entrepreneurship provides a broader insight as it allows for the investigation of new opportunity structures and resource pools that are not limited to ethnic markets and networks (Chaganti and Greene 2002; Dheer 2018; Evansluong 2016). Relocating into new contexts, immigrant entrepreneurs (IEs) are faced with distinctive challenges arising from their non-native status and the liability of newness; these challenges distinguish them from their ethnic and non-ethnic native-born peers (e.g., Rath and Swagerman 2016). Moreover, compared to ethnic entrepreneurs, who tend to remain within their co-ethnic networks, the IEs are prone to break out from these networks into the mainstream networks looking for better opportunities (e.g., Chaganti and Greene 2002; Evansluong et al. 2019; Kitching et al. 2009; Ram et al. 2003). Yet these differences between immigrant and ethnic entrepreneurs are less profound compared to the mainstream nativeborn peers, ${ }^{1}$ in terms of easier mobilization of resources and access to entrepreneurial opportunities (e.g., Aldén and Hammarstedt 2016; Fairlie and Lofstrom 2015; Moghaddam et al. 2017; Yazdanfar and Abbasian 2014). Due to their distinct characteristics, IEs face numerous barriers in securing financing to survive and to grow their ventures (e.g., Barrett et al. 2002; Fraser 2009; Kariv and Coleman 2015); however, the presence of

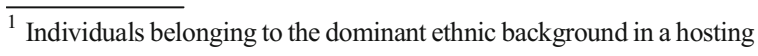
country.
}

these barriers might also prompt the IEs to find innovative ways of overcoming them (c.f. Kloosterman 2003).

The research within entrepreneurial finance, where immigrant entrepreneurial financing is positioned, and as suggested by recent editorials (e.g., Cumming et al. 2019; Cumming and Groh 2018) and reviews (e.g., Hoàng et al. 2020; Shepherd et al. 2020), addresses two overarching questions that are as relevant to entrepreneurial ventures in general as they are to the immigrant ones in particular. These are as follows: how entrepreneurs deal with information asymmetry in financial decisions, and what is the role of investor involvement in portfolio companies. The bibliographic article on entrepreneurial finance by Hoàng et al. (2020) suggests that the field of entrepreneurial finance can be divided into seven main research domains, namely (1) venture capital financing of the entrepreneur; (2) crowdfunding; (3) a venture's activities and financial performance; (4) social entrepreneurship; (5) financial risk; (6) microfinance; and (7) human, social, and financial capital. The first five domains represent the mainstream, while the remaining two domains represent emerging streams of research. While a considerable wealth of knowledge has been accumulated in the field of entrepreneurial finance, the applicability of these domains to immigrant entrepreneurial financing remains scattered.

Despite the topicality of immigrant entrepreneurship, the presence of several thorough reviews on the subject (e.g., Aliaga-Isla and Rialp 2013; Dheer 2018), and the crucial role of finance in immigrants' venturing projects, there is still a lack of systematic knowledge or a complete understanding of entrepreneurial finance applied to immigrant ventures that exhibit unique patterns in addressing the constraints related to their non-native status, liability of newness and network usage (e.g., Assudani 2009; Portes et al. 1999). For instance, constraints on the mainstream market such as lack of language proficiency, limited information access, and discrimination based on ethnic background (e.g., Aldén and Hammarstedt 2016; Hulten and Ahmed 2013) as well as constraints on the co-ethnic market such as high competition for similar or/and limited resources (e.g., Jiobu 1988; Ram et al. 2002) are all the consequences of the IEs' specific features. These multi-contextual constraints make entrepreneurial financing for IEs a distinct phenomenon, which is yet to be differentiated from the field of ethnic entrepreneurial finance.

Given the distinct nature of IEs and their financing patterns, this paper critically and systematically reviews 
the existing knowledge regarding the entrepreneurial finance of immigrant ventures, thereby providing an integrative overview of the current state of the research in this area. It further identifies significant gaps in the current body of knowledge concerning the theoretical and methodological aspects of studying immigrants' entrepreneurial financing, and identifies opportunities for both scholarly and practically relevant future research on the subject.

The remainder of the article is structured as follows: in Section 2, we discuss the method used in the systematic review; Section 3 classifies and discusses the findings and the future research opportunities through a SWOT analysis on the main conceptual areas emerging from the review; finally, the conclusion will be presented in Section 4.

\section{Method}

The aim of this review is to systematically map the research at the intersection between the field of immigrant entrepreneurship and entrepreneurial finance (Briner and Denyer 2012), and then, based on this review and applying a SWOT analysis, to outline future research directions in this field. Conducting a mapping of the research area implies a systematic review of the literature, which requires rigor in the information production and reporting processes (Petticrew and Roberts 2008). To perform a transparent and replicable review, we follow the process outlined by Tranfield et al. (2003). Moreover, we apply the meta-synthesis approach in order to integrate the findings from different empirical studies (Dingwall et al. 1998; Noblit and Hare 1988). We also use the SWOT approach to literature review interpretation, previously employed by Jackson et al. (2003), and H. Li et al. (2020), in order to highlight strengths, weaknesses, threats, and opportunities in the reviewed field. Based on the SWOT interpretation, we propose a future research agenda. The review has been performed in three specific steps, namely review planning, review executions, and data synthesis, the latter also including SWOT analysis.

\subsection{Planning for the review}

In the planning stage, an iterative process of defining, refining, and delineating the scope of the studied topic was implemented (Clarke and Oxman 2001). This process was initiated with the development of a protocol document defining the interdisciplinary scope of the review, the search terms for relevant studies, the selection criteria for these studies, and finally the intended synthesis and analysis approaches that are intended to be applied in the review. The protocol was then iterated and refined through several meetings between the authors and other scholars in the entrepreneurship and finance fields.

The search terms for this review were derived from the adopted delineation of the topic "entrepreneurial finance for immigrant entrepreneurs." The topic scope was defined as the study of financial resourcing (Cumming 2007, 2012; W. R. Kerr et al. 2014) that is required for the IEs to initiate, survive, and grow their economic ventures (e.g., Welter 2011). Accordingly, the search terms focused on the simultaneous occurrence of three aspects: the financing aspect, the entrepreneurial aspect, and the migration aspect. Furthermore, to ensure transparency, we specified three selection criteria for the relevance check of the reviewed studies.

- Selection criterion 1: For quality and comparability purposes, we limited the selection criteria to reputable and scientific peer-reviewed journal articles that are published in the English language.

- Selection criterion 2: The selected articles had to simultaneously and explicitly address the three mentioned aspects of the defined review scope: financing, entrepreneurial, and migration aspects. For instance, articles discussing the entrepreneurial dimensions of immigrant businesses without explicitly discussing the financing aspect were excluded.

- Selection criterion 3: To ensure high quality, we only included articles published in journals that are either listed on the ABS Academic Journal Guide ${ }^{2}$ (ABS 2018) or included in the ESCI/SSCI indices from the Web of Science Journal Citation Reports (Aksnes and Sivertsen 2019). This criterion has an inherited limitation, given that articles published in the journals that were not included in these rankings, as well as dissertations and unpublished reports, were excluded from the review. To partly alleviate this limitation, the unpublished sources which were found by means of an ancestry search have been used throughout the article and where appropriate.

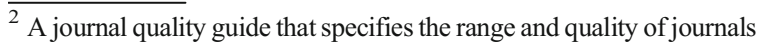
in which business and management academics should publish their research. The ABS Academic Journal guide is published by the Chartered Association of Business Schools.
} 


\subsection{Conducting the review}

This review was initiated in June 2019, and the sample articles were drawn from two databases: Scopus and Web of Science. The reason for choosing these databases was their extensive and interdisciplinary coverage of a wide range of peer-reviewed journals. On the one hand, WOS is known for being one of the oldest databases, with a wide coverage of more than 13,600 peerreviewed journals (Mongeon and Paul-Hus 2016), and extensive citation and bibliographic data that goes back to the year 1900 (Aghaei Chadegani et al. 2013). On the other hand, Scopus is also known for its superior coverage of more than 20,500 peer-reviewed journals from more than 5000 publishers (ibid). Thus, combining those databases is believed to provide deep and extensive coverage of the reviewed topic. The following keywords were used in both databases: "Entrepreneurial financ*" OR "capital financ*" OR "financ* resourc*" OR "venture financ*") AND (“*migrant entrepreneur*" OR "*migrant business*"). The obtained lists from these databases were checked for duplication before being aggregated and subjected to the second criterion of a relevance check, i.e., through screening their titles, abstracts, and keywords.

During the relevance check process, we noticed additional potential articles that had not been obtained through the search process in the databases. Thus, we applied an ancestry search approach. The ancestry approach consists of screening the reference list of the recently published papers identified through a database search to find the original sources on which they relied (Bodolica and Spraggon 2018). The citation analysis procedure continued until no further references were revealed. After performing the ancestral search and identifying relevant studies, we applied the first, second, and third selection criteria, and also checked for duplicates. The total number of resulting articles from the databases and reference lists was 451, of which 358 were excluded for not meeting the second selection criterion of the simultaneous aspects, thus resulting in 93 articles. To arrive at the 93 articles, we primarily dropped articles that exclusively addressed only one of these aspects, for instance, articles that discussed general migration issues. Then, we considered articles that addressed two of the three aspects, with the condition that one of these aspects should be migration. Thus, after a thorough text reading, we dropped irrelevant articles, i.e., those discussing topics such as financial aid to immigrants, immigrant remittances, or immigrant entrepreneurship with no relation to financing. Then, we applied this method again to the studies that were detected through the ancestry search. Moreover, when checking for the second criterion, we identified a certain tendency for some articles to interchangeably use the migration aspect with ethnicity, minority, and race. These articles were put under a category called "potential inclusion/exclusion" for a later full-text assessment by two independent scholars. Consensus rating (c.f. W. R. Clark et al. 2020) was used to decide whether to include or drop them: the rating of 1 means that both scholars agree to include the checked article; otherwise, it is either excluded if the rating is 0 (both disagree) or dropped from the list if the rating is 0.5 (no consensus). As a result of this process, we dropped 41 articles, thereby leaving 52 articles for a quality check according to the third criterion: ABS or ESCI listing. The quality check led to the exclusion of 15 more articles because they did not achieve the listing and ranking requirements, resulting in a final list of 37 relevant studies to be synthesized and analyzed in the next stage (see Prisma in Fig. 2).

\subsection{Data synthesis and analysis}

To illustrate the state of the reviewed field, we adopted the meta-synthesis approach that allows the comparison and interpretation of the integrated data drawn from the reviewed studies (Noblit and Hare 1988). This helps with comparing the different concepts, methods, and theories that were used to study IEs' financing (Sandelowski et al. 1997), and with spotting some potential directions for the future (Tranfield et al. 2003). Using the meta-synthesis approach allowed the application of a critical version of SWOT analysis for assessing the field (c.f. Jackson et al. 2003). This application enabled an interpretation of the field's strengths that could be capitalized on in future research, and revealed weaknesses that should be avoided, opportunities for future advancement, and threats that can hinder such advancement. Our interpretive analysis is based on detailed information extracted from different components of the synthesized studies, namely research problems, methods, results, and conclusions. 


\section{Findings}

In this section, we apply a two-step analysis using a metasynthesis approach to integrate, interpret, and analyze the data drawn from the reviewed studies. First, we provide a descriptive analysis of the current state of the field of entrepreneurial financing for IEs. This is followed by an identification of the field's strengths and weaknesses, potential opportunities, and threats in future research in relation to the main financing aspects, methodologies, and theories used in the studies reviewed.

\subsection{The descriptive analysis of the reviewed field}

Following the general systematic framework outlined by Tranfield et al. (2003) and Briner and Denyer (2012), our descriptive analysis aims at providing a detailed description of the field. For this purpose, we start by describing the chronological and geographical spread of the studies (Fig. 1), and the journals where the contributions to the field were published. Thereafter, we conduct an identification and description of the units and levels of analysis that were covered in these studies. For the units of analysis, we focus on two units: the IEs and the financing means used in the initiation and sustainment of IEs' entrepreneurial ventures. For the level of analysis (similarly to other studies in the field of entrepreneurship), we adopted an ecological typology of different levels of analysis (e.g., Davidsson and Wiklund 2007; Gartner and Shane 1995; Low and MacMillan 1988). This typology includes the individuals themselves, their relationships with their surrounding microsystems (e.g., family, kinships, friendship), their organizations (e.g., immigrant, co-ethnic networks), and localities (e.g., rural, urban). Applying the ecological approach is a convenient way to explore how IEs were recognized in the field, and how their financing endeavors were addressed in relation to their surrounding contexts. Finally, we try to identify the emerging questions in the field regarding the IEs' financing, along with the theories and methods that are used for this purpose.

\subsubsection{The chronological and geographical development of the field}

The chronological review of the studies $(n=37)$ demonstrates an emergence of the field starting in 1996. There were only three publications on the topic between 1995 and 1999. However, the figure also shows a steady increase in publications in the subsequent years until 2019 (Table 1).

Geographically, the studies were primarily performed in North America and Europe. In North America, most of the studies relied on data from the USA, with few studies using Canadian and Puerto Rican data. The European studies primarily relied on data from the UK, with fewer studies using Swedish, German, and other EU data. Yet the review shows a geographical expansion of the field and use of data from other contexts such as Africa, Australia, and the Middle East (Fig. 1).

\subsubsection{Journal publication patterns}

There is a considerable spread in terms of publication outlets. Thirty-seven papers included in the review were published in 25 different journals that belonged to 12 focus areas. Of these 25 journals, 19 were ABS-listed journals ${ }^{3}$ and six were emerging-index journals (Table 2).

\subsubsection{Units of analysis}

Given the inclusion criteria applied in this review, the studies focused on IEs and financing as units of analysis and adopted various definitions of the two concepts.

Defining IEs To define an "immigrant," most of the studies $(n=15)$ used the cultural background as a benchmark to distinguish immigrant individuals, and referred to IEs' ethnic background vis-à-vis the "native-born." "Foreign-born" was another frequently used term $(n=10)$ when referring to the immigrant's place of birth and to make a distinction between immigrants and natives. The act of relocation or/and the legal status of the migration act were sometimes used in addition to the two previously mentioned definitions $(n=4)$. The term "entrepreneur" was used in all studies but was either complemented or used in parallel with the terms "selfemployed" and "business owners." Furthermore, the studies primarily focused on the startups of small businesses, without considering other maturity stages of the IEs' businesses, and focused on the need for the IEs to acquire financing either for initiation of new ventures $(n=21)$ or for the survival of these ventures $(n=17)$. Only fewer studies considered the need for financing for the growth of the IEs' ventures $(n=11)$ (Table 3$)$.

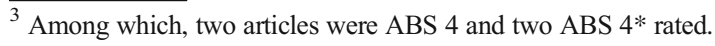


Defining financing The majority of the studies simultaneously addressed the formal and informal means of financing, while there was a lesser tendency to only address the formal or informal means and preferences respectively. Regardless of whether the preferences ${ }^{4}$ were explicitly stated as being formal or informal, the studies addressed a wide spectrum of potential sources for IEs. Most of the articles emphasized informal resources such as loans from family, friends, personal savings, and the co-ethnic community. The formal resources were represented by bank financing, VCs, and other financial institutions (Table 3).

\subsubsection{Levels of analysis}

The studies reviewed dealt with different levels of analysis: individuals; microsystems (e.g., family, kinships, friendship); organizations (e.g., immigrant co-ethnic networks); and localities (e.g., rural, urban). At the individuals' level, the field mainly focuses on the individual IEs (36 out of 37 studies) in relation to their financing choices and barriers on the open market. In these studies, ethnicity, gender, and age were the most frequently covered demographic aspects of the IEs. These demographics were mainly used to explain the IEs' accessibility to finance, e.g., ethnic financing, and associated issues, e.g., discrimination.

At the microsystems level, the focus was primarily on family and friend networks $(n=21)$ as a source for the IEs' financing (Table 4). Few studies $(n=1)$ focused on the role of other microsystems such as work teams or entrepreneurial teams. Especially in relation to family as a microsystem, few studies offered a clear definition of the family, and the term was used interchangeably with other terms, such as "kinships" and "relatives."

Moreover, the review reveals a considerable tendency of the field to consider IEs in their co-ethnic networks (19 out of 37 studies), but very rarely $(n=3)$ in other types of organizations such as immigrant and diasporic networks (Table 4). This could be attributed to the field's focus on the ethnic aspect of IEs at the expense of their migration aspect.

Finally, at the locality level, few studies considered the geographic areas that constitute the physical space of the IEs' interactions with their social systems when

\footnotetext{
${ }^{4}$ These potential resources are those mentioned anywhere in the reviewed articles, and differ from the preferred resources which are identified in the main question or purpose of the reviewed studies.
}

conducting their economic activities. Only 13 out of 37 studies accounted for the IEs' localities, among which 11 studies explored IE within urban areas and two considered the industrial and deprived areas (Table 4). None of the studies explored the financing endeavors of IEs in rural areas.

\subsubsection{The main questions raised in the field}

The review has revealed three main questions that were addressed in the studies: What are the antecedents to the financing decisions on the financing market? What are IE's financing preferences? and What are the financing barriers faced by IEs?

Studies on the antecedents to the financing decisions can generally be separated into those addressing the demand side, representing IEs, and those concerned with the supply side, denoting the formal and informal financiers. For the IEs, factors affecting their financing decisions seem to be clustered within five main groups that intersect the different levels of analysis that were previously discussed. These groups are as follows: IEs' personal-related factors, such as their personal wealth, and their financial sophistication, awareness of, and familiarity with the available financing alternatives, besides the other characteristics related to education and experience; ethnic/social-related factors, such as ethnic homophily, prejudices, and strength of the relational ties with the community; family-related factors, such as the IEs' family wealth, and the family selfishness and altruism; ownership-related factors, such as a preference for less intrusive financing arrangements; and market-related factors, such as limited access to formal financing, and lack of financial information (Table 5).

On the supply side, the review also shows a very similar clustering of six groups of influencing factors: ethnic/social-related factors, such as ethnic homophily, the IEs' race and ethnicity, and prejudices; IEs' personal-related factors, such as the IEs' personal wealth besides the other characteristics related to education and experience; technical-related factors, such as the non-ethnic risk factors related to the IEs' creditworthiness and debt pay-off ability; IEs' business-related factors, such as size, performance, and industry class; family-related factors, such as the family wealth, selfishness, altruism, and socio-economic class; and finally formal institutional factors, such as financial regulations (Table 5). 
A careful look into the abovementioned groups of antecedents shows clear commonalities among them (Table 5). The strongest commonality appears in the ethnic/social group regarding the IEs' and the financiers' ethnic homophily (14 studies), and the prejudices they carry about each other (four studies). This gives an indication of a noticeable tension that has been identified and addressed by the studies between the IEs and their mainstream financiers regarding their ethnic differences. Given its prominence, we adopted this tension as a conceptual reference point in the further analysis of the studies in order to see if it was addressed in the field as a main factor affecting the IEs' financing behavior and accessibility on the open market.

Concerning the third question about the IEs' financing preferences/choices, the reviewed studies confirm informal and co-ethnic resources to be the IEs' primary financing preference. For instance, family, friends, personal savings, and co-ethnic networks were found to be the most discussed financing preferences for IEs in the field (20 studies). However, some formal financing means, especially banks and the co-ethnic VCs (10 studies), were identified in the field as a secondary preference for IEs. These preferences confirm the previously identified tension since they reflect a heavy reliance of IEs on their co-ethnic networks and close social ties for accessing finance in the hosting countries. Finally, despite the scarce evidence (two studies), mixed financing resources were also found to be considered in the field as a tertiary financing preference for IEs (Table 5).

Finally, relevant to the identified tension, different barriers were highlighted in the reviewed studies as hindering the IEs' access to formal and informal financing. These barriers were categorized into four main groups according to their relation to units of analysis and their surrounding context: IE's personal-related barriers, such as their low integration with the new society, and low personal qualifications; IEs' businessrelated barriers, such as the reluctance to control dilution, and poor business performance; financier-related barriers, such as the demographic discrimination against IEs; and context-related barriers, such as the information asymmetry in the market, and the lack of governmental support (Table 5). Although these barriers tend to indicate technical factors related to financial knowledge and performance, they clearly confirm the already indicated tension. This tension was reflected through the high representation of the following terms in the reviewed studies: low integration, demographic discrimination, and asymmetric information. The field shows the existence of a dilemma facing the IEs; however, it barely mentions any factors that could reconcile the tension and thereby facilitate the IEs' access to the necessary finance.

\subsubsection{The methods used in the field}

Of the 37 studies, 27 used a quantitative approach, seven employed a qualitative approach, and only three used a mixed approach (Table 5). The quantitative studies primarily employed various types of regression analysis in addition to ANOVA and descriptive statistics. Seventeen of these studies mainly relied on data drawn from surveys, while 14 used archival data. In the qualitative studies, interviews were used as the primary method of data collection (six studies), while the case study and the thematic and the narrative analyses were the main methods identified in the field. Finally, the mixed methods approach mainly entailed a combined use of descriptive statistics and regression analyses on one hand, and case studies based on the interview data on the other.

\subsubsection{The theoretical perspectives in the field}

Concerning the theories used in explaining the IEs' financing phenomenon in the hosting countries, the review shows that roughly half of the studies (20 of 37 ) clearly mentioned the use of a theory. These 20 studies were found to use 13 different theories that can be grouped into three major categories: finance-, entrepreneurship-, and social-related theories. In the first group, the studies used five theories: the pecking order theory, the paradox theory in finance, the microfinancing and bricolage theory, the information asymmetry theory in finance, and the theory of the discouraged borrower. In the second group, the RBV of entrepreneurship and the entrepreneurship theory were used. Finally, five theories were used in the last group: the social network theory, the social identity theory, the disadvantage theory, the middleman minority theory, and the geographical proximity theory. In this group, it was also noticed that mixed, economic, and relational aspects of the theoretical notion of embeddedness were used (Table 5). 


\subsection{Analysis by means of SWOT}

In this section, we use a meta-synthesis approach in order to compare and interpret the integrated data from the reviewed studies (Jackson et al. 2003). The SWOT analysis was performed on different aspects of the literature, for instance, "the entrepreneurial financing of the immigrant entrepreneurs," which represent the units of analysis in the studies reviewed and the main questions that arose in the field, as well as the theoretical and methodological approaches that were applied when studying the IEs' financing phenomenon. Our SWOT analysis aims at providing an aggregated view of the building blocks on which the field can capitalize, the drawbacks to be avoided, the opportunities to exploit for future advancement, and the threats that could hamper this advancement. In Table 7, we provide an overall demonstration of the identified SWOT items for each of the units of analysis, the emerging questions in the field, and the use of theories and methods in the field. Based on the SWOT mapping, in Table 8, we propose an aggregated list of potential questions for future research.

\subsection{The general "strengths" in the field}

\subsubsection{The entrepreneurial financing of the immigrant entrepreneurs: the units of analysis}

Regarding entrepreneurial financing, no single article was found to explicitly define what entrepreneurial financing was meant to be. However, the general reading of the reviewed articles suggests some degree of alignment with the definition of Cumming (2007) and W. R. Kerr et al. (2014), that is, financial resource allocation for the venture creation. A wide range of formal and informal financing means were covered in the studies, a fact which offers the opportunity to consider a diverse application of the term "entrepreneurial financing" in future research.

Concerning the term "immigrant entrepreneurs" (IEs), we found some attempts to adopt specific references to or definitions of what is meant by the term "immigrants." The review shows frequent use of three main terms to refer to the IEs, namely "ethnic minority," based on the differences in the cultural identity and referring to the IEs as ethnic minority entrepreneurs (e.g., Basu 1998; Bengtsson and Hsu 2015; see more in Table 5); "foreign-born residents," using the differences in the geographical nationality of birth to demonstrate the foreignness of the IEs and to distinguish them from native entrepreneurs (e.g., Aldén and Hammarstedt 2016; Z. Zhang and Reay 2018; see more in Table 5); and finally, "people on the move" using the relocating aspect of migration as a reference benchmark for the IEs (see Table 3) (e.g., Hulten and Ahmed 2013; Tengeh and Nkem 2017; Van Delft et al. 2000; see more in Table 5). Having this multidimensionality in defining "immigrants" indicates the field's tendency to consider the different aspects of this term, which represents the field's strength and allows for replicability of the studies adopting one or several dimensions of the term (see Table 7).

Based on the foreignness and relocation attributes of migration, it is noteworthy to differentiate between the IEs and the native-born peers who belong to either the same or other ethnic backgrounds. On the one hand, despite sharing the same ethnic background, the coethnic native-born peers are assumed to be more integrated in the hosting countries than the newly resettled IEs, and free of the newness liability. Thus, it is contended that they face fewer barriers than the IEs on the open market, and potentially more, or the same, barriers faced by the mainstream native peers. However, due to the shared ethnic background, these co-ethnic native-born peers tend to take part in the same coethnic networks within which IEs capitalize their entrepreneurial endeavors in hosting countries (Portes et al. 1999). In this paper, we focus on the main contrast between the IEs and the native-born peers, i.e., coethnic and mainstream, where the effects of the liabilities of newness and foreignness are assumed to be clear in both groups' pursuit of financing resources.

\subsubsection{The antecedents to the financing decision}

The IEs' accessibility to finance is dependent on some antecedents that shape the financing decision that is taken either on the demand side of the IEs (e.g., Moghaddam et al. 2017; Tengeh and Nkem 2017; see more in Table 5) or on the supply side of the formal and informal financiers (e.g., Ding 2018; Rouse and Jayawarna 2011; see more in Table 5). The plethora of identified antecedents represents the field's strength, providing a nuanced understanding of the IEs' financial decision-making process and of the consequences and barriers that arise from these decisions (e.g., Biggs et al. 2002; Ram et al. 2003; see more in Table 5). Moreover, 
the identification of such antecedents provides clues as to how the barriers can be relaxed for better access to the financing necessary for the IEs' survival and growth (see Table 7).

\subsubsection{The financing preferences/choices}

Two potential strengths can be identified in the field concerning the IEs' financing preferences/choices. First, the wide coverage of the diverse formal (e.g., Aldén and Hammarstedt 2016; Ruiz-Vargas 2000; see more in Table 5), informal (e.g., Bruder et al. 2011; Ostrovsky et al. 2019; Santamaria-Alvarez et al. 2019; see more in Table 5), and mixed financing preferences/choices of IEs in the hosting countries (e.g., Barrett et al. 2002; Haynes et al. 2008; Kariv and Coleman 2015; Sanders and Nee 1996; see more in Table 5). These preferences/ choices were found to be aligned with the IEs' ability to rely on the co-ethnic community, and to simultaneously interact with the other actors in the mainstream contexts (Dheer 2018). Second, the field suggests that IEs possess an ability to simultaneously use financing from formal and informal resources, whether for business initiation (e.g., Abbasian and Yazdanfar 2013; Shinnar et al. 2009), for survival (e.g., Biggs et al. 2002; Haynes et al. 2008), or for growth (e.g., Barrett et al. 2002; Kariv and Coleman 2015; see more in Table 5). Despite the paucity of evidence highlighting the mixed use of financing from the different contexts within which they are embedded, there are some indications of the IEs' ability to simultaneously use mixed sources of financing stemming from their multi-contextual nature (e.g., Biggs et al. 2002; Haynes et al. 2008; Smallbone et al. 2003). It appears that this simultaneous or even ambidextrous ability might serve as an enabler of IEs overcoming difficulties in the formal and informal markets, which subsequently ensures the survival and growth of their ventures (see Table 7).

\subsubsection{The financing barriers}

The field reveals some financing barriers that impede the IEs from accessing the financing means on the open market necessary for their survival and growth. The advantage of this is that identifying the barriers helps to advance our understanding about the reasons why IEs are perceived as undesirable and are denied by the mainstream financiers when they attempt to break out of their co-ethnic networks (e.g., Aldén and
Hammarstedt 2016; Ram et al. 2003). The overview of the field motivates a classification of these barriers into four main categories: the IEs' person-related barriers; the IEs' business-related barriers; the financier-related barriers; and the context-related barriers. However, relevant to the IEs' specific nature, five main barriers can be identified within these categories. First, the low social integration within the hosting community (e.g., Fraser 2009; Hulten and Ahmed 2013; Shinnar et al. 2009) that leads to distrust and discomfort between the IEs and their financiers. Second, the economic integration of the IEs' businesses, represented by their sectoral-class order (e.g., Barrett et al. 2002), constitutes a crucial barrier to their formal financial accessibility. Third, the lack of governmental help and support (e.g., Muchineripi et al. 2019; Van Delft et al. 2000) impedes IEs' access to necessary financial resources. Fourth, IEs are faced with demographic discrimination in the formal credit market, which leads to a high denial rate of their loan applications based on ethnicity, race, gender, age, and socioeconomic class (e.g., Abbasian and Yazdanfar 2013; Aldén and Hammarstedt 2016; J. Zhang et al. 2016; see more in Table 5). Fifth, as a result of being poorly integrated and discriminated against, the IEs face the information asymmetry risk (e.g., Kariv and Coleman 2015; Ostrovsky et al. 2019; see more in Table 5), thus missing out on access to proper information regarding the available financing means and their requirements on the open market. Revealing the reasons behind the existence of these barriers provides potential solutions to the financial alienation and rejection faced by IEs on the open market that hinder their ability to initiate, survive, or grow their economic ventures in hosting countries (see Table 7).

\subsubsection{The theoretical perspectives in the field}

The main strength concerning the application of the theories in the field is represented by the balanced use of different theoretical perspectives in studying and explaining the IEs' financing endeavor in the hosting countries. Theories used can be divided into three main groups: finance-, entrepreneurship-, and social-related theories (see Table 6). In the first group, theories such as the pecking order (e.g., Bruder et al. 2011; Hussain and Matlay 2007; see more in Table 5), the paradox in finance (Z. Zhang and Reay 2018), and microfinancing and bricolage (Kariv and Coleman 2015) are mainly used to discuss the IEs' financing preferences and 
choices as a response to the previously discussed antecedents. Other theories in this group discuss some barriers in accessing financing, for instance, the information asymmetry theory in finance (Biggs et al. 2002), and the theory of the discouraged borrower (Fraser 2009; Hulten and Ahmed 2013). In the second group, the RBV and the entrepreneurship theories are employed to discuss finance as a viable resource for IEs' economic endeavors, and the difficulties they face in accessing credit financing due to their ethnic and other demographic identities (e.g., Rouse and Jayawarna 2011; Yazdanfar and Abbasian 2014; see more in Table 5). In the last group, different socialrelated theories are used, such as the social network theory (Bengtsson and Hsu 2015), the social identity theory (J. Zhang et al. 2016), the disadvantage theory (Shinnar et al. 2009), the middleman minority theory (Sanders and Nee 1996), and the geographical proximity theory (Bird and Wennberg 2016). These theories mainly discuss the enabling and disabling role of the IEs' close social relations and co-ethnic networks in accessing formal and informal financing (see Table 5). The strength concerning the theoretical use in the field is that the current application of theories reflects different aspects of the IEs' financing endeavors in the hosting countries. This use can be further elaborated on and extended in future studies to gain a deeper understanding of these aspects (see Table 7).

\subsubsection{The methods used in the field}

No significant strengths were identified concerning the use of methods in the field. However, related weaknesses, opportunities, and threats will be discussed in a later section.

\subsection{The general weaknesses in the field}

\subsubsection{The entrepreneurial financing of the immigrant entrepreneurs: the units of analysis}

Two main weaknesses were identified concerning the units of analysis: the "immigrant entrepreneurs" and "entrepreneurial financing." First, the term "immigrant entrepreneurs" is observed to be defined in a multidimensional but limited way in the studies reviewed. Namely, despite covering different dimensions of the term "immigrant," i.e., ethnic identity, foreignness, and relocation (e.g., Basu 1998; Hulten and Ahmed 2013;
Z. Zhang and Reay 2018; see more in Table 5), these aspects were seldom integrated with each other, and there was little discussion about the relationship between the terms. The same weakness applies to the other term-"entrepreneurial finance"; despite the wide application of its resource allocation aspect, this application does not replace the necessity of having a specific definition of the term. Adopting a clear and consistent definition for "entrepreneurial financing" could help in setting clear-cut boundaries for its application to the IEs.

Second, the interchangeable use of the terms "immigrant entrepreneurs" and "ethnic entrepreneurs" fails to reveal the differences between these categories of entrepreneurs in terms of their opportunity structures in the hosting countries (Dheer 2018). That is, IEs base the initiation of their economic activities on their co-ethnic networks through which they get access to valuable market and non-market resources ${ }^{5}$ (Bonacich and Light 1988; Portes et al. 1999; Welter 2011). This is linked to their newness in the hosting countries due to their lack of the necessary language, skills, and recognition of qualifications (Assudani 2009; Portes et al. 1999). Therefore, IEs could still be considered as ethnic entrepreneurs since their opportunity structure is still limited to their co-ethnic networks. However, what distinguishes them is their tendency to break out of their traditional co-ethnic networks in response to the demand conditions in the mainstream opportunity structures of their hosting countries (Chaganti and Greene 2002; Evansluong et al. 2019; Kitching et al. 2009). This break-out tendency seems to be associated more with the migration aspect of entrepreneurship than with the ethnic aspect. This is mainly due to the relocation attribute of migration which entails the IEs' ability to draw on prior experiences from home and/or diasporic countries (Kitching et al. 2009; Portes et al. 2002; Saxenian 2002), and mix them with the experience they gain in the hosting countries (e.g., Basu 2011; Portes et al. 1999). This, eventually, provides IEs with a repertoire of business experience that enable them to deal with the different challenges in the mainstream markets (e.g., Hooijberg and Quinn 1992), and thereby to pursue break-out strategies by exploring and exploiting the potential opportunities in these markets. On the other hand, the ethnic aspect alone entails one-sided experience that is usually accumulated through the path

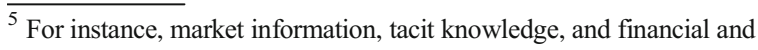
human capital.
} 
dependency by serving ethnic-specific market niches and customers (e.g., Basu 2011; Van Delft et al. 2000). Therefore, ethnic entrepreneurs show a greater tendency to remain within their co-ethnic networks which constitute their comfort zone of business experience, compared to the IEs who tend to break out, benefiting from their more diverse business experience (e.g., Dheer 2018).

Accordingly, the persistence in the use of ethnicity in referring to the IEs might lead to disregarding their mixed embeddedness ${ }^{6}$ feature in the hosting contexts, thereby missing an opportunity to study and understand the different financing patterns that could result from the contextual multiplicity of the IEs (see Table 7).

\subsubsection{The antecedents to the financing decision}

The field's discussion about the antecedents to the financing decisions reveals some weaknesses. First, the field primarily focuses on the general antecedent factors that are usually accounted for when it comes to dealing with financing on the supply and demand sides, regardless of the IEs per se, for instance, factors related to creditworthiness and financial adequacy, such as technical risks (e.g., Fraser 2009; Muchineripi et al. 2019; see more in Table 5), personal- and business-related characteristics (e.g., Bates 1997; Biggs et al. 2002; Rouse and Jayawarna 2011; Smallbone et al. 2003; Yazdanfar and Abbasian 2014; see more in Table 5), and the personal and family wealth (e.g., Haynes et al. 2008; Ruiz-Vargas 2000; Sanders and Nee 1996; see more in Table 5), besides ownership-related factors, such as the dilution effect of external financing (e.g., Frid 2014; Kushnirovich and Heilbrunn 2008; Moghaddam et al. 2017; see more in Table 5). These factors apply for all economic players, including IEs, when dealing with a financing inquiry at the supply and demand sides. Second, regarding the IEs' multicontextual nature, the field tends to scarcely consider the role of institutional context in facilitating or impeding the IEs' access to the formal and informal financing on the open market. IEs are suggested to be exposed to multiple types of institutions that are subject not only to the financing regulations in the formal market (W. $\mathrm{Li}$

\footnotetext{
${ }^{6}$ Referring to the immigrants' integrational function in hosting countries as proposed by Kloosterman et al. (1999), that is, the immigrants' simultaneous engagement within co-ethnic social networks on the one hand, and with the mainstream social, economic, and institutional activities in hosting countries, on the other.
}

et al. 2009) but also to the social norms and conventions between IEs and other players in the informal financing market (Kloosterman et al. 1999). Third, the field solely emphasizes the negative effect of the IEs' reliance on their co-ethnic networks (e.g., Van Delft et al. 2000). This fails to consider the IEs' nature, characterized by their willingness and flexibility to integrate within the hosting contexts in their pursuit of their economic endeavors (e.g., Dheer 2018). Fourth, the field identification of the social/ethnic-based tension as an antecedent to the financial choices of the IEs might only be true when considering their activities in the early stages. However, this discussion requires further elaboration regarding how this tension could be relaxed for the establishment of trust and thick communication channels with formal and informal financiers throughout the IEs' multiple contexts for their survival and growth (see Table 7).

\subsubsection{The financing preferences/choices}

Two main weaknesses related to IEs' financing preferences/choices could be identified in the field. First, while the literature explores preferred financing means for IEs in the hosting countries, the multicontextual nature of IEs remains unaccounted for in these explorations (Kloosterman et al. 1999). This is being revealed by the scarcity of studies discussing the IEs' preference for mixed financing means, and not only in terms of their formality but also regarding their contextuality. The reviewed studies rarely discuss the IEs' ability to use their familiarity with the different contexts when accessing the necessary financial resources. Second, some studies discuss the reliance of ethnic and non-ethnic VCs on the IEs to access the latter's global diasporic networks (Iriyama et al. 2010; Madhavan and Iriyama 2009). However, the literature does not explore the reverse relationship. That is, the current studies scarcely discuss the role of the co-ethnic formal and informal financiers in enabling IEs to learn about and to connect with their non-ethnic financiers. Although this point was partly reflected in the study by Ram et al. (2003) who mention the intermediary role of the IEs' co-ethnic community in facilitating their access to the other formal resources, this topic remains undeveloped and needs further elaboration regarding the mechanisms and outcomes (see Table 7). 


\subsubsection{The financing barriers}

Research dealing with the financing barriers faced by IEs primarily focuses on descriptions of the difficulties of overcoming these barriers, but is limited when it comes to best-practice examples or solutions for overcoming these difficulties. For example, a study by Smallbone et al. (2003) suggests that there is a necessity to improve the IEs' financial knowledge and skills by means of training and education, which will ultimately support their financing eligibility in the formal market. Moreover, Bird and Wennberg (2016) and Moghaddam et al. (2017) emphasize the importance of co-ethnic agents and native family members in bridging the IE and mainstream markets. This bridging facilitates IE's learning and subsequent alleviation of the barriers related to asymmetry of information. However, there is little exploration of the mechanisms that can weaken the barriers experienced by the IEs, and further studies on this topic are needed (see Table 7).

\subsubsection{The theoretical perspectives in the field}

Despite the wide range of theories used in exploring financing aspects of IEs, a number of weaknesses remain. First, the review shows a relatively low tendency to use theories when discussing the IEs' financing pursuits in hosting countries. Roughly half of the reviewed studies did not disclose any theory in their discussions. Second, most of the theories used were found to only discuss the barriers associated with the IEs' financing in the hosting countries, and there were not enough theories highlighting the mitigating solutions to deal with these barriers. This lack might impede any further attempt at making significant advancements in the field, given that, without a systematic discussion about the potential mechanisms, strategies, and solutions concerning the financing tension and barriers faced by IEs in the hosting countries, the field will diminish in its relevance (see Table 7).

\subsubsection{The methods used in the field}

Concerning the research methods used in the field, one can observe a dominance of quantitative studies on the financing endeavors of IEs in their hosting countries (e.g., Basu and Parker 2001; Fatoki 2013; Iriyama et al. 2010; Madhavan and Iriyama 2009; see more in Tables 5 and 6). However, due to the ethnic nature of IEs, and the need to explore and understand the motives behind, and the mechanisms of their financing behavior, the task of knowledge advancement is assumed to require more than just the use of quantitative methods. From this perspective, the dominant use of quantitative methods could be considered a drawback rather than a strength. As such, due to the lesser use of qualitative and mixed methods (e.g., W. Li et al. 2009; SantamariaAlvarez et al. 2019; see more in Tables 5 and 6), research questions such as how the financing decisionmaking process of the IEs in their embeddedness/disembeddedness state looks like, how IEs build their informal financing relations with the co-ethnic and mainstream actors, or how the IEs increase their financing sophistication over time in hosting countries (see Table 7) remain unanswered.

\subsection{The field's opportunities}

\subsubsection{The entrepreneurial financing of the immigrant entrepreneurs: the units of analysis}

Two important opportunities were identified, and pursuing them could help to gain further understanding about the units of analysis. First, the wide application of the entrepreneurial financing functions and the identification of the different aspects of the term "immigrant" offer an opportunity to create clear and comprehensive definitions of the terms "entrepreneurial financing" and "immigrant entrepreneurs." This will allow for a clear and fine-grained delineation of the field of "entrepreneurial financing for IEs" for future research. Second, the adoption of the term "immigrant entrepreneurs" rather than "ethnic entrepreneurs" holds the promise of better understanding of the motives and consequences of the IEs' financing patterns. This adoption would also provide a better reflection of the IEs' multi-contextual embeddedness. Pursuing these opportunities might encourage the needed interdisciplinary work in the field by intertwining the three main topics in immigrant entrepreneurial financing, i.e., entrepreneurship, finance, and migration. This in turn will allow the field to focus on the immigrants', and by extension IEs', disadvantageous situation in hosting countries (e.g., Assudani 2009; Borjas 1986), the complexity of their social 
structures (Hegde and Tumlinson 2014), and the financing needs in the initiation and sustainment of IEs' entrepreneurial endeavors (e.g., Welter 2011). In a similar vein, future research might conduct comparative studies concerning the differences in break-out patterns among IEs of different ethnic backgrounds, which will allow for a better understanding of the ethnic- and migrationspecific attributes of this process (see Table 7).

\subsubsection{The antecedents to the financing decision}

A number of future research opportunities relevant to the antecedents to the IEs' financing decision are suggested. First, so far the field has been primarily preoccupied by identification of financing antecedents in relation to financing preferences in the singular context of the co-ethnic network the IEs are embedded in (e.g., Biggs et al. 2002; Ram et al. 2003). Yet considering the multi-contextual nature of the IEs, future studies could examine the antecedents of IEs' financial decisions in the context of simultaneous embeddedness in both coethnic networks and the mainstream hosting markets. Moreover, despite the extensive use of the term "mixed embeddedness" (e.g., Kloosterman et al. 1999), no detailed discussion about how it is achieved has been undertaken in the field so far. Thus, future research might inquire into whether and how IEs become mixed embedded and what consequences this has for IEs' financing decisions. Second, future studies could further explore how the social/ethnic tension the IEs face on the open market alters as the state of embeddedness changes over time, and how IEs deal with these different forms of tension in terms of their financing choices. Third, future studies might inquire into the role and impact of relevant financial institutions or/and their absence on IEs' financing preferences/choices and their subsequent outcomes (see Table 7).

\subsubsection{The financing barriers and choices}

Our review identified three potential opportunities for future research on the IEs' financing barriers in hosting countries and potential mitigation factors to these barriers. First, future studies could explore the mechanisms through which IEs achieve mixed accessibility to the financing means that are located either in their co-ethnic networks or in the mainstream market. A deeper understanding of the IEs' mixed embeddedness mechanisms might give answers to how IEs learn and develop financial sophistication in their hosting contexts, and how they overcome barriers related to information asymmetry, and relax/neutralize the demographic discrimination against them on the open market. Future studies could inquire into the intermediary role of the co-ethnic community (Ram et al. 2003), represented, for example, by co-ethnic financiers who facilitate the relation between IEs and other mainstream financiers. Future research could further explore the role of "time passage" in enabling IEs to acquire a certain familiarity with the hosting context (Hulten and Ahmed 2013; Hussain and Matlay 2007; Shinnar et al. 2009), thereby becoming mixed embedded over time. Pursuing these avenues might provide a deeper understanding of the practical and institutional factors that trigger the IEs' ability to diversify their financial accessibility in hosting countries. Finally, given the previously highlighted differences between the IEs, and their ethnic and nonethnic native peers in terms of barriers and opportunity structures, future research could explore whether, and how, these types of entrepreneurs differ in their financing mechanisms.

Second, future studies might go even further and explore the role of the strong ties of embeddedness in enhancing the IEs' complex behavioral ability to deal with the contradictory social and institutional requirements in their multiple contexts (Satish 1997). Understanding such ability may help in explaining how IEs mitigate and survive the extreme social and ethnic contradictions with the native players, and thereby how they overcome the potential financing barriers on the financing markets and achieve growth. Accordingly, future studies are also invited to explore the consequences of the IEs' acquired complexity on their perceived preferences and choices for the formal and informal resources in these contexts (see Table 7). Third, future studies could further explore the potential role of government in facilitating the IEs' integration and learning processes which alleviate financing barriers and lead to acceptance of IEs on the financing market (see Table 7).

\subsubsection{The theoretical perspectives in the field}

Several opportunities can be spotted for future advancements concerning the theoretical use in the field. First, 
future research should try to develop the theoretical concept of mixed embeddedness (Kloosterman et al. 1999) into a theory that explains the mechanisms that help IEs to achieve it in the hosting countries. This theoretical development could enable a deeper understanding of how IEs break out of their closed networks and access the mainstream sources of financing in the hosting countries.

Second, a further use of theories from diverse disciplines would provide a variety of lenses to explore financing motivations, tensions, barriers, and solutions, thereby achieving an important advance in the field. For instance, future studies might benefit from the proximity theory, especially its "organized proximity" branch (e.g., Torre and Rallet 2005; Torre and Zuindeau 2009) which uses belongingness and similarity logics to explain why and how co-ethnic actors trust each other and interact within specific social structures. Applying this theory in the field could help to develop knowledge about the ethnic networks as organizations of social relations that are informally governed by specific norms and regulations. That is, this application could enhance our understanding of how these organizations function, how their members initiate and maintain their informal relationships internally, how they interact, and how they initiate relationships with their peers in the external context. In these ways, the application could provide answers to the question of how the IEs break out of these structures and embed themselves into both contexts. Moreover, the structural holes theory (Burt 1992) could be beneficial for complementing the previous theories in explaining the mixed embeddedness state of IEs. The structural holes theory suggests that certain actors can play a brokering role between two networks, thus bridging the flow of information between the players in both networks (Burt 1992, 2002; Burt et al. 2013). This suggests that IEs can benefit from these bridges to learn and become familiar with the hosting context over time, which could be a potential explanation for their embeddedness in the new context (e.g., Obstfeld et al. 2014). Finally, and to gain a further understanding of how IEs develop their financing ability after the mixed embeddedness phase, one could turn to the behavioral complexity theory (e.g., Streufert and Driver 1967; Streufert and Satish 1997). This theory suggests that the thick exchange of knowledge, information, and skills between the IEs and their external peers could enable IEs to accumulate a repertoire of contradictory behaviors from the two contexts they are positioned within (e.g., Denison et al. 1995; Satish 1997; Streufert and Swezey 1986). Applying this theory to the IEs' financing thus could provide an explanation of how IEs become able to use mixed means of financing in both contexts in which they are embedded (see Table 7).

\subsubsection{The methods used in the field}

A potential advancement opportunity in relation to the method would be to increase reliance on qualitative methods. This could develop the field by uncovering the motivations and mechanisms that determine the IEs' formal and informal financing behavior in the hosting countries. In relation to the multi-contextual nature of IEs (Dheer 2018), ethnographic methods might offer a valuable research tool for developing new insights (O'reilly 2012). Future studies might consider the use of observation of IEs and the patterns of their socialization as a data collection method. Using this approach, being in continuous contact with IEs would enable the researcher to gain a deeper insight into their distinct financing behavior within and outside their coethnic networks. This would enable a deeper understanding of how IEs make their financing decisions under different circumstances, how they conduct their informal financing with the co-ethnic and mainstream actors, and how they increase their financial ability in a contextual multiplicity (see Table 7).

\subsection{The field's threats}

\subsubsection{Entrepreneurial financing of the immigrant entrepreneurs: the units of analysis}

The potential threat associated with the definition and identification of the units of analysis is represented by the interchangeable and time-inconsequent use of different, albeit related, terms, i.e., "ethnicity," "race," or "minority" to refer to non-native 
entrepreneurs. This use of terms creates frequent confusion as to whether the studies deal with biological, national, regional, or self-perceptional dimensions of cultural identity, and whether IEs' identity is composed of some or all of these dimensions (which could be the case). The literature exploring the entrepreneurial financing of ethnic minorities that have for generations inhabited one given country has shown a tendency to label these minorities as "immigrant entrepreneurs." Similarly, the literature applying the label "immigrant entrepreneurs" also explores differences in entrepreneurial financing in relation to racio-ethnicity, where only biological attributes of culture have been in focus and without consideration of the migration or relocation aspects of the individuals under study. Moreover, some studies use the term "minority entrepreneurs" to refer to entrepreneurs belonging to any minority group, not necessarily ethnic or immigrant, but also racial minority groups (e.g., Asian or African in the USA), religious minority groups (e.g., Hindus in the UK), gender minority groups, or even indigenous minority groups (e.g., Māori people in New Zealand), again claiming they have "immigrant status." These types of labeling inconsistencies were reflected in the considerable number of studies that were excluded from the review. This exclusion was performed by the means of consensus test where studies claiming an immigrant entrepreneurship focus have in reality observed race or/and ethnic minority or minority status without considering IEs' defining features. The inconsistent and interchangeable use of terms like "race," "religion," "ethnicity," and "gender" that are applied in a mutually exclusive way when referring to IEs calls for the adoption of a clear, specific, and comprehensive definition of the term "immigrant entrepreneurs" that considers all the related cultural, physical, and spatial aspects, such as race, minority, ethnicity, foreignness, and relocation (see Table 7).

\subsubsection{The financing antecedents, barriers, and choices}

Two prominent ethnic-related threats may impede future aspirations to gain further understanding of the IEs' financing decision antecedents, as well as the financing barriers and choices faced by the IEs in hosting countries. First, while the literature acknowledges the diversity and complexity of the IEs' social structures in the hosting countries (Hegde and Tumlinson 2014), it fails to deeply probe the composition of these structures. The diversity of these structures refers to the multiplicity of the ethnic cultural backgrounds that co-exist in a specific country, whereas their complexity is attributed to the idiosyncrasy of the cultural norms governing the relationships in these structures. Failure to consider how such structures function impedes the advancement of the exploration of the IEs' financing decision-making process and the mechanisms through which the ethnic tensions in the open market could be reduced.

Second, the informality of the IEs' economic activities (Kloosterman et al. 1999) might impede the traceability of the IEs' informal financing choices and preferences. The relationships among the co-ethnic players are usually based on trust and interpersonal confidence (Assudani 2009), where economic transactions might be verbally pledged. Accordingly, counting on conventional formal means to follow their informal financing transactions rather than getting into their complex relational networks might be a futile endeavor. Moreover, the informality of IEs' economic transactions and the privacy of their co-ethnic relationships might cause reluctance to disclose the sources of financing. In this case, tracking informal transactions between close ethnic ties could be an extremely sensitive task (see Table 7). Consequently, dealing with the complexity and informality of the IEs' social structures becomes an urgent task to account for in future research.

\subsubsection{The theoretical perspectives in the field}

Two threats could be identified in this domain. First, the particularity of each ethnic case threatens the applicability of the same theoretical framework to all cases. Theories that can explain and predict some cases might not work on others, which implies the need for a generic theoretical framework that has a flexible applicability to a wider spectrum of ethnic cases. Second, the multi-contextual nature of the IEs seems to require the use of multiple theories to complement our understanding of their financing behavior in the hosting countries. Thus, a harmonized use of different theories in this regard could represent a serious challenge for researchers. 
Accordingly, future studies must be vigilant for any potential collision in their theoretical construct when conducting research on the topic of entrepreneurial financing of IEs (see Table 7).

\subsubsection{The methods used in the field}

Two potential threats can be identified regarding the methods used in the field. First, regarding the conduct of quantitative research methods, the availability of data about the informal financial transactions of IEs might be out of reach, especially transactions conducted with the co-ethnic peers. Second, carrying out qualitative research methods, especially those based on observation and socialization, might be a difficult task. The researchers' deep accessibility to the necessary information about the IEs' business and financial affairs might not be welcomed by the IEs due to the sensitivity of such information. Thus, trust and identity might play an essential role in the success of this task, which must be considered by the researcher as a critical part of the research planning (see Table 7).

\section{Conclusion}

Despite the urgency of issues related to growing migration flows and the increasing number of studies discussing IEs, the knowledge of the immigrants' entrepreneurial financing remains rather blurred and incomplete. Therefore, in this study, we critically and systematically reviewed the field of entrepreneurial financing of IEs, provided a comprehensive picture of the current state of the field, identified the existing gaps, and suggested potential opportunities for future development. This was achieved by means of a two-step analysis on 37 systematically selected articles. In the first part of the review, we provided a rough-cut description of the overall state of the field, while in the second part we conducted a SWOT analysis on the field's units of analysis, the main questions, and the use of methods and theories in the field. The analysis allowed us to define some building blocks for the field's future advancement. The review further identified some weaknesses and gaps in these aspects, suggesting potential opportunities for future research, and highlighted potential threats that might prevent the implementation of the suggested research opportunities.

Considering the gaps identified by means of the SWOT analysis, we suggest how these can be filled, and propose further questions to be raised for the advancement of the field. Specifically, the future research questions can be grouped as shown in Table 8, with the key aspects revolving around (1) the boundaries of the subjects' "immigrant entrepreneurship" and "entrepreneurial financing," a comprehensive definition of which is critical not only for scholarly purposes but also for policy aims. For instance, it could help policymakers to develop efficient policies that can facilitate the IEs' embeddedness in hosting countries through initiating governmental agencies that play direct intermediation roles between them and the formal financiers on the open market; (2) The antecedents to the financing decision-making, both on the supply and demand sides, and the related structural, socio-cultural, and behavioral aspects. For instance, further inquiries could focus on the role of the IEs' state of embeddedness in hosting countries, which can mitigate or escalate the social/ethnic tension the IEs face in the mainstream markets. Additionally, future research could further explore the mechanisms the IEs use when experiencing different forms of tension in the mainstream markets. Finally, research in the field could put further effort into understanding the role of institutions in shaping IEs' financing choices, for instance, the informal regulations that govern the social and financial relationships in each of the co-ethnic and mainstream contexts; the role of relaxing the formal financial regulations in enabling easier access for IEs to the necessary financing; and the awareness of the potential consequences of the collision between the formal and informal financial regulations on the IEs' financial access; (3) The behavioral, cognitive, and social dimensions related to the choice and mix of financing channels. For instance, research could explore the mechanisms through which the IEs are able to achieve mixed financial accessibility in their co-ethnic networks and/or the mainstream markets. Particular focus in this domain might be put on the bridging role of the co-ethnic financiers 
in facilitation of the relationship between the IEs and the other financiers on the open market. Moreover, future inquiries could be directed toward the role of the strong ties of embeddedness and in relation to IEs' development of complex behavioral ability in meeting the contradictory financing requirements in their multiple contexts. Lastly, researchers in the field could explore how IEs' acquired complexity and familiarity with the different contexts relates to their financing preferences and choices; (4) The barriers that are found to hinder the IEs' financing preferences and choices and how IEs activate behavioral strategies and abilities to overcome such tensions and barriers. For instance, exploration of the mechanisms that help effectively bridge IEs with the other constituents in the hosting context could be one potential avenue for research. Further inquiries could be made into the role of mixed embeddedness in shaping IEs' financial sophistication, and reduction of their exposure to information asymmetry in the hosting countries. Additionally, future studies could explore the role mixed embeddedness might play in relaxing or neutralizing the demographic discrimination against the IEs on the open market. Understanding the role of the exchange mechanisms of knowledge, information, and skills in mitigating the financing barriers could be yet another future research path. Exploration of the factors enabling IEs to learn and build their complex behavioral ability to mitigate and survive the financing barriers existing in the financing markets in hosting countries could further add to the development of the field. Lastly, understanding the role of government in facilitating the IEs' integration, learning processes, and acceptance in the financing market could be an additional future research topic; (5) The use of theories and methods in the field that would enable the researchers to follow up with the proposed questions. For instance, future research could embark on the application of new theories that could explore and explain the ambiguous mechanisms in the IEs' financing behavior in hosting countries. Moreover, the field might benefit from intensifying the use of the qualitative methods for a deeper understanding of the motivations and mechanisms of the IEs' formal and informal financing behavior in the hosting countries.

\section{Limitations}

Our systematic review of the field of the entrepreneurial financing for the IEs comes with some limitations. First, our review only uses two databases which, despite their longstanding and broad-coverage bibliographies, leave space for the omission of contributions that might exist in other databases. We tried to alleviate this risk by applying the ancestry search approach to the recently published papers, which yielded a few additional articles as well as two doctoral dissertations that were referred to in this paper. Second, in line with the set inclusion and exclusion criteria, we only included studies published in the English language, which could have led to the omission of relevant studies in other languages. Third, for quality and comparability purposes, we limited the selection criteria to peer-reviewed journal articles that were either ABS-listed or included in the ESCI/SSCI indices from the Web of Science Journal Citation Reports. This was done to partly ensure the quality of the manuscripts under review. Finally, due to our focus on the IEs on the one hand, and the considerable number of studies that mix the migration aspect with ethnicity, minority, and race on the other hand, extracting the articles that focused on migration as defining feature of IEs was a challenging task. Thus, despite having a consensus assessment for the inclusion/exclusion of the articles conducted by independent scholars, we cannot discount the possibility of the omission of relevant studies. Similarly, as per the second selection criteria in the Section 2, the selected studies should simultaneously address the migration and the financing aspects of the IEs in their titles, abstracts, and keywords. This exposes our systematic search to the risk of excluding studies that have dealt with immigrant entrepreneurs but were less explicit in their focus on financing. Yet the risk was partly alleviated by performing the ancestry search that helped identifying papers with less explicit focus on financing in their abstracts and keywords, but still useful for the review.

Funding Open Access funding provided by Jönköping University. 


\section{Appendix 1}

Table 1 The chronological development of the field

\begin{tabular}{ll}
\hline Time periods & No. of studies \\
\hline Pre-1990 & 0 \\
$1990-1994$ & 0 \\
$1995-1999$ & 3 \\
$2000-2004$ & 8 \\
$2005-2010$ & 10 \\
$2011-2015$ & 7 \\
$2015-2019$ & 9 \\
\hline
\end{tabular}

Table 2 Journal publication patterns

\begin{tabular}{|c|c|c|c|}
\hline Source title & $\begin{array}{l}\text { No. of } \\
\text { studies }\end{array}$ & $\begin{array}{l}\mathrm{ABS} \\
\text { rating }\end{array}$ & $\begin{array}{l}\text { Citation } \\
\text { index }\end{array}$ \\
\hline American Sociological Review & 1 & $4 *$ & SSCI \\
\hline Asia-Pacific Journal of Financial Studies & 1 & - & SSCI \\
\hline Entrepreneurship and Regional Development & 1 & 3 & SSCI \\
\hline $\begin{array}{l}\text { Environment and Planning C-Government } \\
\text { and Policy }\end{array}$ & 2 & 3 & - \\
\hline $\begin{array}{l}\text { International Journal of Entrepreneurial } \\
\text { Behavior and Research }\end{array}$ & 3 & 2 & SSCI \\
\hline $\begin{array}{l}\text { International Journal of Gender and } \\
\text { Entrepreneurship }\end{array}$ & 1 & 2 & - \\
\hline International Small Business Journal & 2 & 3 & SSCI \\
\hline Journal of Business Venturing & 3 & 4 & SSCI \\
\hline Journal of Developmental Entrepreneurship & 4 & - & ESCI \\
\hline $\begin{array}{l}\text { Journal of Economic Behavior \& } \\
\text { Organization }\end{array}$ & 1 & 3 & SSCI \\
\hline Journal of Economics & 1 & 2 & SSCI \\
\hline Journal of Ethnic and Migration Studies & 1 & - & SSCI \\
\hline Journal of International Business Studies & 1 & $4 *$ & SSCI \\
\hline $\begin{array}{l}\text { Journal of International Migration and } \\
\text { Integration }\end{array}$ & 1 & - & ESCI \\
\hline $\begin{array}{l}\text { Journal of Small Business and Enterprise } \\
\text { Development }\end{array}$ & 3 & 2 & ESCI \\
\hline $\begin{array}{l}\text { Journal of Small Business and } \\
\text { Entrepreneurship }\end{array}$ & 1 & 1 & - \\
\hline Kyklos & 1 & 3 & SSCI \\
\hline Oxford Bulletin of Economics and Statistics & 1 & 3 & SSCI \\
\hline Quarterly Review of Economics and Finance & 1 & 2 & ESCI \\
\hline Small Business Economics & 1 & 3 & SSCI \\
\hline Strategic Entrepreneurship Journal & 2 & 4 & SSCI \\
\hline Sustainability & 1 & - & SSCI \\
\hline $\begin{array}{l}\text { The Journal for Transdisciplinary Research } \\
\text { in Southern Africa }\end{array}$ & 1 & - & ESCI \\
\hline $\begin{array}{l}\text { Venture Capital: an International Journal of } \\
\text { Entrepreneurial Finance }\end{array}$ & 1 & 2 & ESCI \\
\hline $\begin{array}{l}\text { World Review of Entrepreneurship, } \\
\text { Management and Sustainable } \\
\text { Development }\end{array}$ & 1 & 1 & - \\
\hline
\end{tabular}

The asterisk indicates an 'elite' level of the business journal ranking in the ABS
Table 3 Units of analysis

Immigrant definition

No. of studies

Different ethnic/cultural backgrounds than the native-born

Foreign-born

People on the move

3

Admitted for permanent residence

Entrepreneurship terminologies

Self-employment

Business owners

5

Necessity entrepreneurs

Business maturity

Startup

Startup and established

Idea stage

Idea and later stages

Financing aims

Business initiation

Business survival

Business growth

Covered financing means

Formal financing

Bank financing

Other financial institutions (credit card companies, leasing companies, saving companies, brokerage firms, finance companies, etc.)

$\mathrm{VC}$ financing

Governmental financing

Angel investors

Grants from enterprise 1 programs/employer/team members

Informal financing

Loans from family

Loans from friends

Personal savings

Ethnic/communal network financing

Trade credit from suppliers

Credit unions 
Table 4 Levels of analysis

\begin{tabular}{ll}
\hline Individual entrepreneurs & No. of studies \\
Considering individual immigrant entrepreneurs & 36 \\
Not considering individual immigrant & 1 \\
$\quad$ entrepreneurs & \\
Types of covered microsystems & \\
Family & 21 \\
Friends & 16 \\
Kinships & 4 \\
Team members & 1 \\
Types of covered organizations & \\
Ethnic network & 19 \\
Diasporic networks & 2 \\
Immigrant networks & 1 \\
Types of covered localities & \\
Urban areas & 11 \\
Industrial areas & 1 \\
Deprived & 1 \\
\hline
\end{tabular}

Table 5 The fields' raised questions and use of theories and methods

\begin{tabular}{|c|c|c|c|c|c|c|}
\hline Authors & $\begin{array}{l}\text { Method } \\
\text { nature }\end{array}$ & Used theory & $\begin{array}{l}\text { Antecedents for } \\
\text { financing decision } \\
\text { (demand) }\end{array}$ & $\begin{array}{l}\text { Antecedents for } \\
\text { financing decision } \\
\text { (supply) }\end{array}$ & $\begin{array}{l}\text { Preferred financing } \\
\text { for IEs and (financing } \\
\text { aims) }\end{array}$ & $\begin{array}{l}\text { Financing } \\
\text { barriers }\end{array}$ \\
\hline $\begin{array}{l}\text { Abbasian and } \\
\text { Yazdanfar (2013) }\end{array}$ & Quant. & E-ship theory & n.a. & $\begin{array}{l}\text { The IEs' charac.: age, } \\
\text { gender, ethnicity, } \\
\text { side job, net-wealth }\end{array}$ & $\begin{array}{l}\text { Informal: family. } \\
\text { Formal: bank loans; } \\
\text { (initiation) }\end{array}$ & $\begin{array}{l}\text { Personal } \\
\text { qualifica- } \\
\text { tions. } \\
\text { Discr.: age, } \\
\text { gender, } \\
\text { ethnic }\end{array}$ \\
\hline $\begin{array}{l}\text { Aldén \& } \\
\text { Hammarstedt } \\
\text { (2016) }\end{array}$ & Quant. & n.a. & n.a. & Prejudices & Bank loans; (survival) & Discr.: ethnic \\
\hline Barrett et al. (2002) & Quant. & $\begin{array}{l}\text { The theoretical } \\
\text { notion: mixed } \\
\text { embeddednes- } \\
\mathrm{s}\end{array}$ & $\begin{array}{l}\text { Ethnic homophily. The } \\
\text { IEs' charac.: Own } \\
\text { wealth }\end{array}$ & Sector class & $\begin{array}{l}\text { Informal: personal } \\
\text { savings, co-ethnic } \\
\text { network. Formal: } \\
\text { banks; (growth) }\end{array}$ & $\begin{array}{l}\text { Poor } \\
\text { integration: } \\
\text { economic }\end{array}$ \\
\hline Basu (1998) & Quant. & n.a. & $\begin{array}{l}\text { The IEs' charac.: own } \\
\text { wealth }\end{array}$ & n.a. & $\begin{array}{l}\text { Personal savings; } \\
\text { (growth) }\end{array}$ & - \\
\hline $\begin{array}{l}\text { Basu and Parker } \\
\text { (2001) }\end{array}$ & Quant. & n.a. & Selfishness and altruism & $\begin{array}{l}\text { Selfishness and } \\
\text { altruism }\end{array}$ & $\begin{array}{l}\text { Family; (initiation and } \\
\text { survival) }\end{array}$ & Psychological \\
\hline Bates (1997) & Quant. & n.a. & n.a. & $\begin{array}{l}\text { The IEs' charac.: } \\
\text { family wealth; } \\
\text { education }\end{array}$ & $\begin{array}{l}\text { Informal: family } \\
\text { wealth (equity). } \\
\text { Formal: bank loans; } \\
\text { (initiation and } \\
\text { survival) }\end{array}$ & - \\
\hline $\begin{array}{l}\text { Bengtsson and Hsu } \\
\quad(2015)\end{array}$ & Quant. & $\begin{array}{l}\text { Social network } \\
\text { theory }\end{array}$ & Ethnic homophily & Ethnic homophily & $\begin{array}{l}\text { Co-ethnic VC; } \\
\text { (survival and } \\
\text { growth) }\end{array}$ & - \\
\hline Biggs et al., (2002) & Mixed & & $\begin{array}{l}\text { The IEs' charac.: family } \\
\text { wealth }\end{array}$ & $\begin{array}{l}\text { The IEs' charac.: } \\
\text { reputation }\end{array}$ & $\begin{array}{l}\text { Informal: trade credit; } \\
\quad \text { (survival) }\end{array}$ & \\
\hline
\end{tabular}


Table 5 (continued)

\begin{tabular}{|c|c|c|c|c|c|c|}
\hline Authors & $\begin{array}{l}\text { Method } \\
\text { nature }\end{array}$ & Used theory & $\begin{array}{l}\text { Antecedents for } \\
\text { financing decision } \\
\text { (demand) }\end{array}$ & $\begin{array}{l}\text { Antecedents for } \\
\text { financing decision } \\
\text { (supply) }\end{array}$ & $\begin{array}{l}\text { Preferred financing } \\
\text { for IEs and (financing } \\
\text { aims) }\end{array}$ & $\begin{array}{l}\text { Financing } \\
\text { barriers }\end{array}$ \\
\hline & & $\begin{array}{l}\text { Information } \\
\text { asymmetry in } \\
\text { finance }\end{array}$ & & & & $\begin{array}{l}\text { Personal } \\
\text { qualifica- } \\
\text { tions }\end{array}$ \\
\hline $\begin{array}{l}\text { Bird and Wennberg } \\
\quad(2016)\end{array}$ & Quant. & $\begin{array}{c}\text { The theoretical } \\
\text { notion of }\end{array}$ & $\begin{array}{l}\text { social/relational } \\
\text { embeddedness; e-ship; } \\
\text { proximity (geographi- } \\
\text { cal) }\end{array}$ & Prejudices & n.a. & $\begin{array}{l}\text { Family; } \\
\text { (survival or } \\
\text { exit) }\end{array}$ \\
\hline \multicolumn{7}{|c|}{ 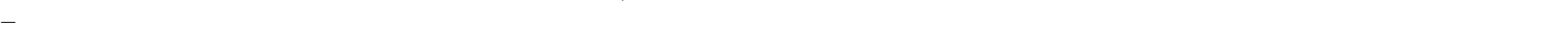 } \\
\hline Bruder et al. (2011) & Quant. & $\begin{array}{l}\text { Pecking order } \\
\text { theory in } \\
\text { finance }\end{array}$ & n.a. & $\begin{array}{l}\text { Non-ethnic risk; poor } \\
\text { integration }\end{array}$ & $\begin{array}{l}\text { Informal: family, } \\
\text { friends; (initiation) }\end{array}$ & $\begin{array}{l}\text { Discr.: ethnic; } \\
\text { Information } \\
\text { asymmetry }\end{array}$ \\
\hline Ding (2018) & Quant. & n.a. & Prejudices & Ethnic homophily & $\begin{array}{l}\text { Co-ethnic VC; } \\
\quad \text { (initiation) }\end{array}$ & - \\
\hline Fatoki (2013) & Quant. & n.a. & Prejudices & n.a. & $\begin{array}{l}\text { Bootstrapping; } \\
\quad \text { (survival) }\end{array}$ & - \\
\hline Fraser (2009) & Quant. & $\begin{array}{c}\text { The theory of } \\
\text { discouraged } \\
\text { borrowers }\end{array}$ & $\begin{array}{l}\text { Ethnic homophily; } \\
\text { awareness of the } \\
\text { available financing } \\
\text { alternatives; financial } \\
\text { sophistication (time } \\
\text { passage); preference for } \\
\text { less intrusive tools }\end{array}$ & Non-ethnic risk & $-;$ (survival) & $\begin{array}{l}\text { Poor financial } \\
\text { perfor- } \\
\text { mance and } \\
\text { skills; poor } \\
\text { integration }\end{array}$ \\
\hline Frid (2014) & Quant. & $\begin{array}{l}\text { Pecking order } \\
\text { theory }\end{array}$ & n.a. & n.a. & $\begin{array}{l}\text { Informal: family, } \\
\text { friends and } \\
\text { co-ethnic network; } \\
\text { (initiation) }\end{array}$ & - \\
\hline Haynes et al. 2008) & Quant. & n.a. & $\begin{array}{l}\text { Strength of relational ties } \\
\text { with the financial } \\
\text { institutions; preference } \\
\text { for less intrusive tools }\end{array}$ & $\begin{array}{c}\text { The IEs' charac.: } \\
\text { family wealth }\end{array}$ & $\begin{array}{c}\text { Formal: banks, finance } \\
\text { companies, credit } \\
\text { card companies. } \\
\text { Informal: family, } \\
\text { friends; (survival) }\end{array}$ & - \\
\hline $\begin{array}{l}\text { Hulten and Ahmed } \\
\qquad \text { (2013) }\end{array}$ & Quant. & $\begin{array}{c}\text { The theory of } \\
\text { discouraged } \\
\text { borrowers }\end{array}$ & $\begin{array}{l}\text { Awareness of the available } \\
\text { financing alternatives } \\
\text { (time passage); } \\
\text { information asymmetry }\end{array}$ & n.a. & $\begin{array}{l}\text { Informal: family and } \\
\text { friends; (initiation } \\
\text { and survival) }\end{array}$ & $\begin{array}{l}\text { Information } \\
\text { asymmetry; } \\
\text { poor integ. }\end{array}$ \\
\hline $\begin{array}{l}\text { Hussain and Matlay } \\
\text { (2007) }\end{array}$ & Qual. & $\begin{array}{l}\text { Pecking order } \\
\text { theory in } \\
\text { small } \\
\text { businesses }\end{array}$ & Ethnic homophily & n.a. & $\begin{array}{l}\text { Informal: family, } \\
\text { co-ethnic network, } \\
\text { trade credit; (initia- } \\
\text { tion and survival) }\end{array}$ & Diluted control \\
\hline Iriyama et al. (2010) & Quant. & n.a. & n.a. & $\begin{array}{l}\text { Ethnic homophily; } \\
\text { global mobilization } \\
\text { of IEs. }\end{array}$ & -; (initiation) & - \\
\hline $\begin{array}{l}\text { Kariv and Coleman } \\
\qquad(2015)\end{array}$ & Quant. & $\begin{array}{l}\text { Microfinance } \\
\text { theory and the } \\
\text { theory of } \\
\text { bricolage; } \\
\text { RBV }\end{array}$ & $\begin{array}{l}\text { The IEs' charac: } \\
\text { own/family capital }\end{array}$ & n.a. & $\begin{array}{l}\text { Microloans from any } \\
\text { source (formal, } \\
\text { informal); } \\
\text { (initiation, survival, } \\
\text { and growth) }\end{array}$ & $\begin{array}{l}\text { Information } \\
\text { asymmetry }\end{array}$ \\
\hline $\begin{array}{l}\text { Kushnirovich and } \\
\text { Heilbrunn (2008) }\end{array}$ & Quant. & $\begin{array}{l}\text { The resources } \\
\text { theory of } \\
\text { entrepreneur- } \\
\text { ship }\end{array}$ & $\begin{array}{l}\text { Awareness of the available } \\
\text { financing alternatives; } \\
\text { financial sophistication } \\
\text { (time passage) }\end{array}$ & n.a. & $\begin{array}{l}\text { Informal: personal } \\
\text { savings. Formal: } \\
\text { gov. designated } \\
\text { loans; (initiation, } \\
\text { survival, and } \\
\text { growth) }\end{array}$ & Interference \\
\hline \multirow[t]{2}{*}{ Li et al. (2009) } & Qual. & n.a. & Ethnic homophily & $\begin{array}{l}\text { Ethnic capitalization } \\
\text { (ethnic asset); } \\
\text { financial regulations }\end{array}$ & $-;(\mathrm{N} / \mathrm{A})$ & - \\
\hline & Quant. & n.a. & & & $-;(\mathrm{N} / \mathrm{A})$ & - \\
\hline
\end{tabular}


Table 5 (continued)

\begin{tabular}{|c|c|c|c|c|c|c|}
\hline Authors & $\begin{array}{l}\text { Method } \\
\text { nature }\end{array}$ & Used theory & $\begin{array}{l}\text { Antecedents for } \\
\text { financing decision } \\
\text { (demand) }\end{array}$ & $\begin{array}{l}\text { Antecedents for } \\
\text { financing decision } \\
\text { (supply) }\end{array}$ & $\begin{array}{l}\text { Preferred financing } \\
\text { for IEs and (financing } \\
\text { aims) }\end{array}$ & $\begin{array}{l}\text { Financing } \\
\text { barriers }\end{array}$ \\
\hline $\begin{array}{l}\text { Madhavan and } \\
\text { Iriyama (2009) }\end{array}$ & & & $\begin{array}{l}\text { Ethnic homophily; } \\
\text { familiarity with the } \\
\text { formalities of the FIs in } \\
\text { the hosting countries }\end{array}$ & $\begin{array}{l}\text { The FIs' social } \\
\text { embeddedness; } \\
\text { global mobilization } \\
\text { of IEs }\end{array}$ & & \\
\hline $\begin{array}{l}\text { Moghaddam et al. } \\
\text { (2017) }\end{array}$ & Qual. & $\begin{array}{l}\text { Pecking order } \\
\text { theory }\end{array}$ & $\begin{array}{l}\text { Ethnic homophily; } \\
\text { information asymmetry }\end{array}$ & n.a. & $\begin{array}{l}\text { Informal: } \\
\text { bootstrapping. } \\
\text { Formal: local bank } \\
\text { loans; (growth) }\end{array}$ & Diluted control \\
\hline $\begin{array}{l}\text { Muchineripi et al. } \\
\text { (2019) }\end{array}$ & Qual. & n.a. & n.a. & Non-ethnic risk & -; (initiation) & $\begin{array}{l}\text { Information } \\
\text { asymmetry; } \\
\text { lack of gov. } \\
\text { support }\end{array}$ \\
\hline $\begin{array}{l}\text { Ostrovsky et al. } \\
\text { (2019) }\end{array}$ & Quant. & Pecking order & n.a. & n.a. & $\begin{array}{l}\text { Informal: family, } \\
\text { friends, co-ethnic } \\
\text { network; (growth) }\end{array}$ & $\begin{array}{l}\text { Information } \\
\text { asymmetry }\end{array}$ \\
\hline Ram et al. (2003) & Qual. & n.a. & $\begin{array}{l}\text { The IEs' charac: family } \\
\text { wealth }\end{array}$ & $\begin{array}{l}\text { The IEs' charac.: } \\
\text { ethnicity, race }\end{array}$ & $\begin{array}{l}\text { Informal: personal } \\
\text { savings and support } \\
\text { agencies; (growth) }\end{array}$ & $\begin{array}{l}\text { Discr.: ethnic, } \\
\text { race }\end{array}$ \\
\hline $\begin{array}{l}\text { Rouse and } \\
\quad \text { Jayawarna (2011) }\end{array}$ & Quant. & $\begin{array}{l}\text { Social inclusion; } \\
\text { RBV of e-ship }\end{array}$ & n.a. & $\begin{array}{l}\text { The IEs' charac.: } \\
\text { socio-economic } \\
\text { class }\end{array}$ & -; (initiation) & $\begin{array}{l}\text { Discr.: } \\
\text { inter-- } \\
\text { minority, } \\
\text { social class }\end{array}$ \\
\hline Ruiz-Vargas (2000) & Quant. & n.a. & n.a. & $\begin{array}{l}\text { The IEs' charac.: own } \\
\text { wealth; ethnic } \\
\text { homophily }\end{array}$ & $\begin{array}{l}\text { Bank loans; (initiation, } \\
\text { survival, and } \\
\text { growth) }\end{array}$ & - \\
\hline $\begin{array}{l}\text { Sanders and Nee } \\
\text { (1996) }\end{array}$ & Quant. & $\begin{array}{l}\text { Theory of } \\
\text { middleman } \\
\text { minorities }\end{array}$ & $\begin{array}{l}\text { The IEs' charac: } \\
\text { own/family capital }\end{array}$ & $\begin{array}{l}\text { Family socio-economic } \\
\text { class and social cap- } \\
\text { ital: reputation }\end{array}$ & $\begin{array}{l}\text { Family, co-ethnic cred- } \\
\text { it association. For- } \\
\text { mal: co-ethnic lend- } \\
\text { ing institutions; (ini- } \\
\text { tiation) }\end{array}$ & $\begin{array}{l}\text { Low social } \\
\text { status }\end{array}$ \\
\hline $\begin{array}{l}\text { Santamaria-Alvarez } \\
\text { et al. (2019) }\end{array}$ & Qual. & n.a. & $\begin{array}{l}\text { Ethnic homophily. The } \\
\text { IEs' charac: own capital, } \\
\text { high education, } \\
\text { language proficiency, } \\
\text { experience }\end{array}$ & n.a. & $\begin{array}{l}\text { Informal: personal } \\
\text { savings, co-ethnic } \\
\text { network; (growth) }\end{array}$ & - \\
\hline Shinnar et al. (2009) & Quant. & $\begin{array}{l}\text { The } \\
\text { disadvantage } \\
\text { theory }\end{array}$ & $\begin{array}{l}\text { Awareness of the available } \\
\text { financing alternatives; } \\
\text { financial sophistication } \\
\text { (time passage) }\end{array}$ & n.a. & $\begin{array}{l}\text { Informal: family and } \\
\text { friends; (initiation) }\end{array}$ & $\begin{array}{l}\text { Poor financial } \\
\text { skills; poor } \\
\text { integ. }\end{array}$ \\
\hline $\begin{array}{l}\text { Smallbone et al. } \\
\text { (2003) }\end{array}$ & Mixed & n.a. & Ethnic homophily & $\begin{array}{l}\text { The IEs' and business } \\
\text { charac.: gender, } \\
\text { potential } \\
\text { performance }\end{array}$ & $\begin{array}{l}\text { Formal: banks. } \\
\text { Informal: family and } \\
\text { friends; (initiation } \\
\text { and survival) }\end{array}$ & $\begin{array}{l}\text { Poor financial } \\
\text { perfor- } \\
\text { mance and } \\
\text { skills; } \\
\text { gender } \\
\text { discr. }\end{array}$ \\
\hline $\begin{array}{l}\text { Tengeh and Nkem } \\
\text { (2017) }\end{array}$ & Mixed & n.a. & $\begin{array}{l}\text { Ethnic homophily; } \\
\text { familiarity with the } \\
\text { formalities of the FIs in } \\
\text { the hosting countries }\end{array}$ & n.a. & $\begin{array}{l}\text { Informal: personal } \\
\text { savings, families, } \\
\text { friends and ethnic } \\
\text { financial } \\
\text { associations; } \\
\text { (initiation and } \\
\text { growth) }\end{array}$ & $\begin{array}{l}\text { Poor } \\
\text { familiarity } \\
\text { with the } \\
\text { formal } \\
\text { financial } \\
\text { sector }\end{array}$ \\
\hline $\begin{array}{l}\text { Van Delft et al. } \\
\text { (2000) }\end{array}$ & Quant. & n.a. & $\begin{array}{l}\text { Ethnic homophily; } \\
\text { awareness of the } \\
\text { available financing } \\
\text { alternatives }\end{array}$ & n.a. & $\begin{array}{l}\text { Co-ethnic network; } \\
\quad \text { (initiation) }\end{array}$ & $\begin{array}{l}\text { Lack of gov. } \\
\text { support; } \\
\text { information } \\
\text { asymmetry }\end{array}$ \\
\hline
\end{tabular}


Table 5 (continued)

\begin{tabular}{|c|c|c|c|c|c|c|}
\hline Authors & $\begin{array}{l}\text { Method } \\
\text { nature }\end{array}$ & Used theory & $\begin{array}{l}\text { Antecedents for } \\
\text { financing decision } \\
\text { (demand) }\end{array}$ & $\begin{array}{l}\text { Antecedents for } \\
\text { financing decision } \\
\text { (supply) }\end{array}$ & $\begin{array}{l}\text { Preferred financing } \\
\text { for IEs and (financing } \\
\text { aims) }\end{array}$ & $\begin{array}{l}\text { Financing } \\
\text { barriers }\end{array}$ \\
\hline $\begin{array}{l}\text { Yazdanfar and } \\
\text { Abbasian (2014) }\end{array}$ & Quant. & E-ship theory & n.a. & $\begin{array}{l}\text { The IEs' and business } \\
\text { charac.: side job, } \\
\text { education, own } \\
\text { capital, business } \\
\text { size, legal status, } \\
\text { industry }\end{array}$ & $\begin{array}{l}\text {-; (initiation and } \\
\text { survival) }\end{array}$ & $\begin{array}{l}\text { Personal } \\
\text { qualifica- } \\
\text { tions; } \\
\text { business } \\
\text { characteris- } \\
\text { tics }\end{array}$ \\
\hline Zhang et al. (2016) & Quant. & $\begin{array}{l}\text { Social identity } \\
\text { theory }\end{array}$ & n.a. & Ethnic homophily & $-;(\mathrm{N} / \mathrm{A})$ & $\begin{array}{l}\text { Discr.: ethnic; } \\
\text { low social } \\
\text { status }\end{array}$ \\
\hline $\begin{array}{l}\text { Zhang and Reay } \\
\text { (2018) }\end{array}$ & Qual. & $\begin{array}{l}\text { Paradox theory } \\
\text { in finance }\end{array}$ & $\begin{array}{l}\text { The IEs' charac: family } \\
\text { wealth }\end{array}$ & n.a. & $\begin{array}{l}\text { Informal: family } \\
\text { savings; (initiation } \\
\text { and survival) }\end{array}$ & Interference \\
\hline
\end{tabular}

Table 6 Methods and theories

\begin{tabular}{|c|c|c|c|}
\hline Nature of the used methods & No. of studies & Used theories & No. of studies \\
\hline Quantitative & 27 & Finance-related & \\
\hline Qualitative & 7 & Pecking order theory & 5 \\
\hline Mixed & 3 & The theory of discouraged borrowers & 2 \\
\hline \multicolumn{2}{|c|}{ Data collection technique in quantitative method } & Information asymmetry in finance & 1 \\
\hline Interviews & 6 & Paradox theory in finance & 1 \\
\hline \multicolumn{2}{|l|}{ Qualitative method name methods } & Microfinance theory and financial bricolage & 1 \\
\hline Case study & 1 & E-ship-related & \\
\hline Field observations & 1 & E-ship theory & 3 \\
\hline Narrative research paradigm & 1 & RBV of e-ship & 3 \\
\hline Thematic analysis & 1 & Social-related & \\
\hline \multicolumn{2}{|c|}{ Data collection technique in quantitative method } & Embeddedness: mixed, economic, relational & 1 \\
\hline Archival data & 14 & Social network theory & 1 \\
\hline Survey & 13 & Social identity theory & 1 \\
\hline Interview survey (face to face survey) & 1 & Proximity theory: geographic & 1 \\
\hline Online survey & 1 & Theory of middleman minorities & 1 \\
\hline Mail and telephone survey & 1 & The disadvantage theory & \\
\hline Case study survey & 1 & & \\
\hline
\end{tabular}


Table 7 The comprehensive SWOT table

\begin{tabular}{llll}
\hline Fields' strengths & Fields' weaknesses & Field's opportunities & Field's threats
\end{tabular}

Unit of analysis: the entrepreneurial financing and the immigrant entrepreneurs

Diverse coverage of the formal and informal financing means.

Considering diverse aspects in No comprehensive definition of the defining the term "immigrant." term "immigrant entrepreneurs."

The interchangeable use of the terms "ethnic entrepreneurs" and "immigrant entrepreneurs."

The antecedents to the financing decision

Allows the identification of
the financing
preferences/choices,
tensions, barriers, and
mitigating factors.

Main focus on the general creditworthiness antecedents for the financing decision on the supply side.

Little consideration of the role of the institutional context on the financing decision.

High focus on the IEs' reliance on their co-ethnic network, and omitting the integrative nature of the IEs.

The financing preferences/choices

\section{Wide coverage of the IEs' financing preferences/choices which \\ The coverage does not suitably reflect the true multi-contextual nature of IEs.} are aligned with the IEs' multiple nature.

Indication of the ability of IEs Lack of discussion of the role of the to simultaneously use financing from formal and informal resources.

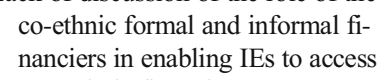
non-ethnic financiers.
The financing barriers

Identifying the financing barriers helps in understanding the reasons finance is denied to IEs by mainstream financiers.
Most studies focus on the financing difficulties and barriers faced by the IEs, without proposing effective solutions to overcome them.
The theoretical use in the field

The balanced use of theories Low use of theories in the field. in studying and explaining
To create a fine-grained definition using wide coverage.

To create a fine-grained and comprehensive definition based on the covered aspects.

Adopting the term "immigrant" in future studies enables understanding of the motives and consequences of their financing patterns.

Examining the change in the IEs' financing antecedents in a mixed embeddedness state in the hosting countries.

Exploring how the social/ethnic tension transforms in case of the IEs' mixed embeddedness state.

Understanding the impact of the lack of financial institutions on the IEs' financing decision.

Exploring how IEs achieve mixed accessibility to financing means.

Understanding the role of co-ethnic financiers in bridging the relationship between the IEs and the other financiers on the open market.

Understanding how IEs develop their complex behavioral ability, and its impact on their financing preferences and choices.

Exploring the differences in the financing mechanisms between the IEs, and their ethnic and non-ethnic native peers.

Exploring the mitigating role of mixed embeddedness, government support, and the exchange mechanisms in improving the IEs' financial sophistication and complex ability, in order to reduce their exposure to the different financing barriers in the hosting countries.

The ability to use different theories to explain some ambiguous
The habit in the literature of using ethnicity, race, or minority terms to refer to non-native entrepreneurs.

The complexity of the IEs' social structures impedes understanding of the impact of the informal norms on the IEs' financing decision-making process.

The informality of their economic activities might impede the traceability of the IEs' informal financing choices and preferences.

Potential reluctance of IEs to disclose their sources of financing.

The complexity of the IEs' social ethnic structures; the ambiguity of their embeddedness and learning mechanisms; and the difficult traceability of their financing relations.

The inability of single theories to comprehensively explain or 
Table 7 (continued)

\begin{tabular}{|c|c|c|c|}
\hline Fields' strengths & Fields' weaknesses & Field's opportunities & Field's threats \\
\hline \multirow[t]{2}{*}{$\begin{array}{l}\text { the IEs' financing } \\
\text { endeavors in the hosting } \\
\text { countries. }\end{array}$} & & $\begin{array}{l}\text { mechanisms in the IEs' financing } \\
\text { endeavors. }\end{array}$ & $\begin{array}{l}\text { predict the IEs' financing behavior } \\
\text { due to the particularity of the } \\
\text { different ethnic contexts. }\end{array}$ \\
\hline & $\begin{array}{l}\text { Most of the used theories only } \\
\text { discuss the IEs' financing } \\
\text { difficulties, with not enough } \\
\text { theories to suggest mitigating } \\
\text { solutions to these barriers. }\end{array}$ & & $\begin{array}{l}\text { The multiple use of theories might } \\
\text { threaten the consistency of the } \\
\text { aspired theoretical framework. }\end{array}$ \\
\hline \multicolumn{4}{|c|}{ The use of methods in the field } \\
\hline \multirow[t]{2}{*}{$\begin{array}{l}\text { No significant strength was } \\
\text { identified. }\end{array}$} & $\begin{array}{l}\text { The dominant use of quantitative } \\
\text { studies is not enough to explore } \\
\text { the IEs' financing motivations, } \\
\text { barriers, and mechanisms. }\end{array}$ & $\begin{array}{l}\text { Intensifying the use of qualitative } \\
\text { methods in researching the } \\
\text { motivations and mechanisms of } \\
\text { the IEs' formal and informal } \\
\text { financing behavior in the hosting } \\
\text { countries. }\end{array}$ & $\begin{array}{l}\text { Regarding the conduct of quantitative } \\
\text { methods, data about the informal } \\
\text { financial transactions of IEs might } \\
\text { be out of reach. }\end{array}$ \\
\hline & & & $\begin{array}{l}\text { Regarding the conduct of qualitative } \\
\text { methods, the researchers' } \\
\text { accessibility to the IEs' financing } \\
\text { information might not be } \\
\text { welcomed by the IEs due to the }\end{array}$ \\
\hline
\end{tabular}

Table 8 The emerging questions for future research

The units of analysis

- How can the terms "entrepreneurial financing" and "immigrant entrepreneurs" be comprehensively defined in a fine-gained way?

The antecedents to the financing decision

- What antecedents could emerge when the IEs become mixed embedded in their hosting countries?

- How does the social/ethnic tension the IEs face on the open market alters according to their changing state of embeddedness over time?

- How do IEs deal with the different forms of tension in terms of their financing choices?

- What is the impact of the lack of financial institutions on the IEs' financing decision?

- How do IEs manage and survive the contradictions in the formal and informal financing institutions that escalate the tension in their multiple contexts?

The financing preferences/choices

- How do IEs achieve multiple accessibility to the financing means that are located either in their co-ethnic networks or in the mainstream market?

- What is the role of the co-ethnic financiers in bridging the relationship between the IEs and the other financiers on the open market?

- What is the role of the strong ties of embeddedness in developing the IEs' complex behavioral ability to meet the contradictory financing requirements in their multiple contexts?
Table 8 (continued)

- What are the consequences of the IEs' acquired behavioral complexity and familiarity with the different contexts on their perception of the financing preferences and choices?

- How do the IEs differ in their financing mechanisms from their ethnic and non-ethnic native peers?

The financing barriers

- What mechanisms would effectively bridge IEs with the other constituents in the hosting context?

- What is the role of mixed embeddedness in improving the IEs' financial sophistication, and reducing their exposure to information asymmetry in the hosting countries?

- What is the role of mixed embeddedness in relaxing or neutralizing the demographic discrimination against the IEs on the open market?

- What is the role of the exchange mechanisms of knowledge, information, and skills in mitigating the financing barriers? - How do IEs learn and build their complex behavioral ability to mitigate and survive the financing barriers existing in the financing markets in hosting countries?

- What is the role of government in facilitating the IEs' integration, learning processes, and acceptance in the financing market?

- What is the potential role of government in the absence of the financing alternatives?

The use of methods and theories

- What theories can be used to explain the ambiguous mechanisms in the IEs' financing behavior?

- Would intensified use of qualitative methods be useful for researching the motivations and mechanisms of the IEs' formal and informal financing behavior in the hosting countries? 


\section{Appendix 2}

Fig. 1 The geographical spread of the field
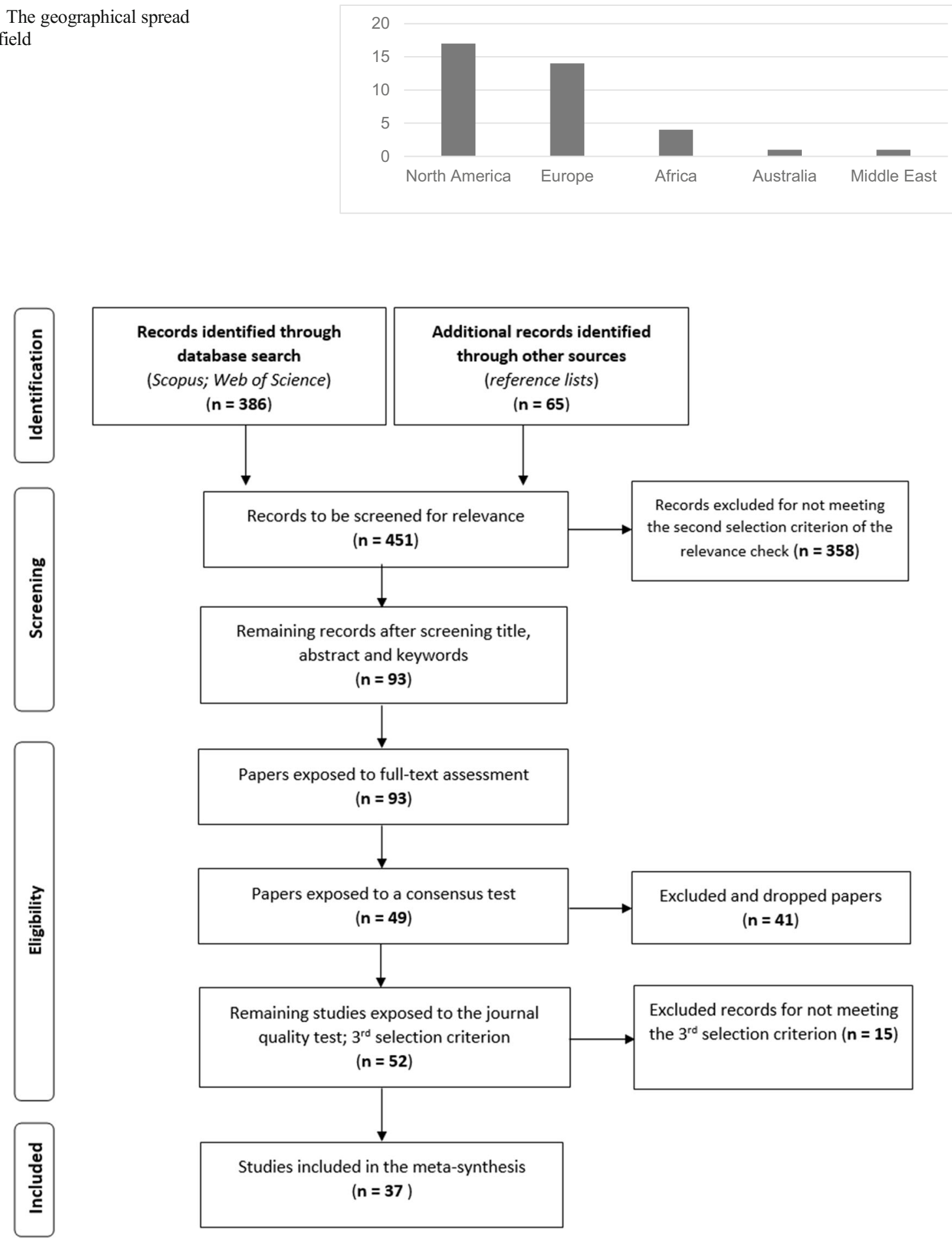

Fig. 2 Prisma chart 
Open Access This article is licensed under a Creative Commons Attribution 4.0 International License, which permits use, sharing, adaptation, distribution and reproduction in any medium or format, as long as you give appropriate credit to the original author(s) and the source, provide a link to the Creative Commons licence, and indicate if changes were made. The images or other third party material in this article are included in the article's Creative Commons licence, unless indicated otherwise in a credit line to the material. If material is not included in the article's Creative Commons licence and your intended use is not permitted by statutory regulation or exceeds the permitted use, you will need to obtain permission directly from the copyright holder. To view a copy of this licence, visit http://creativecommons.org/licenses/by/4.0/.

\section{References}

Abada, T., Hou, F., \& Lu, Y. (2014). Choice or necessity: Do immigrants and their children choose self-employment for the same reasons? Work, Employment and Society, 28(1), 78-94. https://doi.org/10.1177/0950017013511870.

Abbasian, S., \& Yazdanfar, D. (2013). Exploring the financing gap between native born women-and immigrant womenowned firms at the start-up stage: Empirical evidence from Swedish data. International Journal of Gender and Entrepreneurship, 5(2), 157-173. https://doi.org/10.1108 /17566261311328837.

ABS. (2018). Academic journal guide. London: Chartered Association of Business Schools.

Achidi Ndofor, H., \& Priem, R. L. (2011). Immigrant entrepreneurs, the ethnic enclave strategy, and venture performance. Journal of Management History, 37(3), 790-818. https://doi. org/10.1177/0149206309345020.

Aghaei Chadegani, A., Salehi, H., Yunus, M., Farhadi, H., Fooladi, M., Farhadi, M., \& Ale Ebrahim, N. (2013). A comparison between two main academic literature collections: Web of Science and Scopus databases. Asian Social Science, 9(5), 18-26. https://doi.org/10.5539/ass.v9n5p18.

Aksnes, D. W., \& Sivertsen, G. (2019). A criteria-based assessment of the coverage of Scopus and Web of Science. Journal of Data and Information Science, 4(1), 1-21. https://doi. org/10.2478/jdis-2019-0001.

Aldén, L., \& Hammarstedt, M. (2016). Discrimination in the credit market? Access to financial capital among self-employed immigrants. Kyklos, 69(1), 3-31. https://doi.org/10.1111 /kykl.12101.

Aliaga-Isla, R., \& Rialp, A. (2013). Systematic review of immigrant entrepreneurship literature: Previous findings and ways forward. Entrepreneurship and Regional Development, 25(9-10), 819844. https://doi.org/10.1080/08985626.2013.845694.

Assudani, R. H. (2009). Ethnic entrepreneurship: The distinct role of ties. Journal of Small Business and Entrepreneurship, 22(2), 197-205. https://doi.org/10.1080/08276331.2009.10593450.

Barrett, G., Jones, T., McEvoy, D., \& McGoldrick, C. (2002). The economic embeddedness of immigrant enterprise in Britain. International Journal of Entrepreneurial Behavior \& Research, 8(1/2), 11-31. https://doi.org/10.1108 /13552550210423697.
Basu, A. (1998). The role of institutional support in Asian entrepreneurial expansion in Britain. Journal of Small Business and Enterprise Development, 5(4), 317-326. https://doi. org/10.1108/EUM0000000006796.

Basu, A. (2011). From 'break out' to 'breakthrough': Successful market strategies of immigrant entrepreneurs in the UK. International Journal of Entrepreneurship and Innovation Management, 15,1 .

Basu, A., \& Parker, S. C. (2001). Family finance and new business start-ups. Oxford Bulletin of Economics and Statistics, 63(3), 333-358. https://doi.org/10.1111/1468-0084.00224.

Bates, T. (1997). Financing small business creation: The case of Chinese and Korean immigrant entrepreneurs. Journal of Business Venturing, 12(2), 109-124. https://doi.org/10.1016 /S0883-9026(96)00054-7.

Bates, T., Bradford, W. D., \& Seamans, R. (2018). Minority entrepreneurship in twenty-first century America. Small Business Economics, 50(3), 415-427. https://doi. org/10.1007/s11187-017-9883-5.

Bengtsson, O., \& Hsu, D. H. (2015). Ethnic matching in the US venture capital market. Journal of Business Venturing, 30(2), 338-354. https://doi.org/10.1016/j.jbusvent.2014.09.001.

Bewaji, T., Yang, Q., \& Han, Y. (2015). Funding accessibility for minority entrepreneurs: An empirical analysis. Journal of Small Business and Enterprise Development, 22(4), 716733. https://doi.org/10.1108/JSBED-08-2012-0099.

Biggs, T., Raturi, M., \& Srivastava, P. (2002). Ethnic networks and access to credit: Evidence from the manufacturing sector in Kenya. Journal of Economic Behavior \& Organization, 49(4), 473-486. https://doi.org/10.1016/S0167-2681(02 )00030-6.

Bird, M., \& Wennberg, K. (2016). Why family matters: The impact of family resources on immigrant entrepreneurs' exit from entrepreneurship. Journal of Business Venturing, 31(6), 687-704. https://doi.org/10.1016/j.jbusvent.2016.09.002.

Bodolica, V., \& Spraggon, M. (2018). An end-to-end process of writing and publishing influential literature review articles. Management Decision, 56(11), 2472-2486. https://doi. org/10.1108/MD-03-2018-0253.

Bonacich, E., \& Light, I. (1988). Immigrant entrepreneurs: Koreans in Los Angeles.

Borjas, G. J. (1986). The self-employment experience of immigrants. Journal of Human Resources, 21(4), 485-506. https://doi.org/10.3386/w1942.

Borjas, G. J. (2014). Immigration economics. Cambridge: Harvard University Press.

Briner, R. B., \& Denyer, D. (2012). Systematic review and evidence synthesis as a practice and scholarship tool. Handbook of evidence-based management: Companies, Classrooms and Research, 112-129. doi:https://doi.org/10.1093 /oxfordhb/9780199763986.013.0007.

Bruder, J., Neuberger, D., \& Räthke-Döppner, S. (2011). Financial constraints of ethnic entrepreneurship: Evidence from Germany. International Journal of Entrepreneurial Behaviour and Research, 17(3), 296-313. https://doi. org/10.1108/13552551111130727.

Burt, R. S. (1992). Structural holes: The social structure of competition. Cambridge: Harvard University Press.

Burt, R. S. (2002). The social capital of structural holes. The new economic sociology: Developments in an Emerging Field, 148(90). 
Burt, R. S., Kilduff, M., \& Tasselli, S. (2013). Social network analysis: Foundations and frontiers on advantage. Annual Review of Psychology, 64, 527-547. https://doi.org/10.1146 /annurev-psych-113011-143828.

Cederberg, M., \& Villares-Varela, M. (2019). Ethnic entrepreneurship and the question of agency: The role of different forms of capital, and the relevance of social class. Journal of Ethnic and Migration Studies, 45(1), 115-132. https://doi. org/10.1080/1369183X.2018.1459521.

Chaganti, R., \& Greene, P. G. (2002). Who are ethnic entrepreneurs? A study of entrepreneursapos; ethnic involvement and business characteristics. Journal of Small Business Management, 40(2), 126-143. https://doi.org/10.1111 /1540-627X.00045.

Chrysostome, E. (2010). The success factors of necessity immigrant entrepreneurs: In search of a model. Thunderbird International Business Review, 52(2), 137-152. https://doi. org/10.1002/tie.20320.

Clark, K., \& Drinkwater, S. (2000). Pushed out or pulled in? Selfemployment among ethnic minorities in England and Wales. Labour Economics, 7(5), 603-628. https://doi.org/10.1016 /S0927-5371(00)00015-4.

Clark, W. R., Clark, L. A., Raffo, D. M., \& Williams, R. I. (2020). Extending Fisch and Block's (2018) tips for a systematic review in management and business literature. Management Review Quarterly, 1-17. doi:https://doi.org/10.1007/s11301020-00184-8.

Clarke, M., \& Oxman, A. D. (2001). Assessment of study quality. Cochrane reviewers handbook 4.1. 1 [updated December 2000]. The Cochrane Library, (1).

Cumming, D. (2007). Government policy towards entrepreneurial finance: Innovation investment funds. Journal of Business Venturing, 22(2), 193-235. https://doi.org/10.1016/j. jbusvent.2005.12.002.

Cumming, D. (Ed.). (2012). The oxford handbook of entrepreneurial finance. Oxford: Oxford University Press.

Cumming, D., \& Groh, A. P. (2018). Entrepreneurial finance: Unifying themes and future directions. Journal of Corporate Finance, 50, 538-555. https://doi.org/10.1016/j. jcorpfin.2018.01.011.

Cumming, D., Deloof, M., Manigart, S., \& Wright, M. (2019). New directions in entrepreneurial finance. Journal of Banking \& Finance, 100, 252-260. https://doi.org/10.1016 /j.jbankfin.2019.02.008.

Davidsson, P., \& Wiklund, J. (2007). Levels of analysis in entrepreneurship research: Current research practice and suggestions for the future. In Entrepreneurship. Springer, Berlin, Heidelberg, pp. 245-265. doi:https://doi.org/10.1007/978-3540-48543-8_12.

Denison, D. R., Hooijberg, R., \& Quinn, R. E. (1995). Paradox and performance: Toward a theory of behavioral complexity in managerial leadership. Organization Science, 6(5), 524 540. https://doi.org/10.1287/orsc.6.5.524.

Dheer, R. J. (2018). Entrepreneurship by immigrants: A review of existing literature and directions for future research. International Entrepreneurship and Management Journal, 14(3), 555-614. https://doi.org/10.1007/s11365-018-0506-7.

Ding, N. (2018). Ethnic ties in US venture capital stage financing. Asia-Pacific Journal of Financial Studies, 47(2), 306-328. https://doi.org/10.1111/ajfs.12212.
Dingwall, R., Murphy, E., Watson, P., Greatbatch, D., \& Parker, S. (1998). Catching goldfish: Quality in qualitative research. Journal of Health Services Research \& Policy, 3(3), 167172. https://doi.org/10.1177/135581969800300308.

Drori, I., Honig, B., \& Wright, M. (2009). Transnational entrepreneurship: An emergent field of study. Entrepreneurship: Theory and Practice, 33(5), 1001-1022. https://doi. org/10.1111/j.1540-6520.2009.00332.x.

Evansluong, Q. (2016). Opportunity creation as a mixed embedding process: A study of immigrant entrepreneurs in Sweden (doctoral dissertation).

Evansluong, Q., Pasillas, M. R., \& Bergström, H. N. (2019). From breaking-ice to breaking-out: Integration as an opportunity creation process. International Journal of Entrepreneurial Behavior \& Research, 25(5), 880-899. https://doi. org/10.1108/IJEBR-02-2018-0105.

Fairlie, R. W., \& Lofstrom, M. (2015). Immigration and entrepreneurship. In Handbook of the economics of international migration, 1, 877-911. North-Holland. doi: 10419/90116.

Fatoki, O. (2013). An investigation into the financial bootstrapping methods used by immigrant entrepreneurs in South Africa. Journal of Economics and Management Strategy, 4(2), 89-96. https://doi.org/10.1080 /09765239.2013.11884968.

Fraser, S. (2009). Is there ethnic discrimination in the UK market for small business credit? International Small Business Journal: Researching Entrepreneurship, 27(5), 583-607. https://doi.org/10.1177/0266242609338756.

Freeland, R. E., \& Keister, L. A. (2016). How does race and ethnicity affect persistence in immature ventures? Journal of Small Business Management, 54(1), 210-228. https://doi. org $/ 10.1111 /$ jsbm. 12138 .

Frid, C. J. (2014). Acquiring financial resources to form new ventures: The impact of personal characteristics on organizational emergence. Journal of Small Business and Entrepreneurship, 27(3), 323-341. https://doi.org/10.1080 /08276331.2015.1082895.

Gartner, W. B., \& Shane, S. A. (1995). Measuring entrepreneurship over time. Journal of Business Venturing, 10(4), 283161. https://doi.org/10.1016/0883-9026(94)00037-U.

Haynes, G. W., Onochie, J. I., \& Lee, Y. (2008). Influence of family's social relationship on the debt structure of MexicanAmerican and Korean-American small businesses. Journal of Developmental Entrepreneurship, 13(3), 343-361. https://doi.org/10.1142/S1084946708001022.

Hegde, D., \& Tumlinson, J. (2014). Does social proximity enhance business partnerships? Theory and evidence from ethnicity's role in U.S. venture capital. Management Science, 60(9), 2355-2380. https://doi.org/10.1287 /mnsc.2013.1878.

Hoàng, N. M., Huyen, N. T. T., Pham, T. H., Nguyen, Q. Y. T., \& Vuong, Q. H. (2020). A bibliometric study on the research landscape of entrepreneurial finance from 1970-2019. doi: https://doi.org/10.31219/osf.io/qf62s

Hooijberg, R., \& Quinn, R. E. (1992). Behavioral complexity and the development of effective managers.

Hulten, A. V., \& Ahmed, A. D. (2013). Migrant entrepreneurs' access to business finance in Australia. Journal of Developmental Entrepreneurship, 18 (1). doi:https://doi. org/10.1142/S1084946713500039. 
Hunt, J. (2011). Which immigrants are most innovative and entrepreneurial? Distinctions by entry visa. Journal of Labor Economics, 29(3), 417-457. https://doi.org/10.1086/659409.

Hunt, J. (2015). Are immigrants the most skilled US computer and engineering workers? Journal of Labor Economics, 33(S1), S39-S77. https://doi.org/10.1086/678974.

Hunt, J., \& Gauthier-Loiselle, M. (2010). How much does immigration boost innovation? American Economic Journal: Macroeconomics, 2(2), 31-56. https://doi.org/10.1257 /mac.2.2.31.

Hussain, J., \& Matlay, H. (2007). Financing preferences of ethnic minority owner/managers in the UK. Journal of Small Business and Enterprise Development, 14(3), 487-500. https://doi.org/10.1108/14626000710773565.

Iriyama, A., Li, Y., \& Madhavan, R. (2010). Spiky globalization of venture capital investments: The influence of prior human networks. Strategic Entrepreneurship Journal, 4(2), 128145. https://doi.org/10.1002/sej.87.

Jackson, S. E., Joshi, A., \& Erhardt, N. L. (2003). Recent research on team and organizational diversity: SWOT analysis and implications. Journal of Management History, 29(6), 801830. https://doi.org/10.1016/S0149-2063(03)00080-1.

Jiobu, R. M. (1988). Ethnic hegemony and the Japanese of California. American Sociological Review, 353-367.

Jones, T., Ram, M., \& Villares-Varela, M. (2019). Diversity, economic development and new migrant entrepreneurs. Urban Studies, 56(5), 960-976. https://doi.org/10.1177 /0042098018765382.

Kahn, S., La Mattina, G., \& MacGarvie, M. J. (2017). "Misfits," "stars," and immigrant entrepreneurship. Small Business Economics, 49(3), 533-557. https://doi.org/10.1007 /s11187-017-9848-8.

Kariv, D., \& Coleman, S. (2015). Toward a theory of financial bricolage: The impact of small loans on new businesses. Journal of Small Business and Enterprise Development, 22(2), 196-224. https://doi.org/10.1108/JSBED-02-2013-0020.

Kerr, W. R., Lerner, J., \& Schoar, A. (2014). The consequences of entrepreneurial finance: Evidence from angel financings. The Review of Financial Studies, 27(1), 20-55. https://doi. org/10.1093/rfs/hhr098.

Kerr, S. P., Kerr, W. R., \& Lincoln, W. F. (2015). Skilled immigration and the employment structures of US firms. Journal of Labor Economics, 33(1), 147-186. https://doi.org/10.1086 1678986.

Kitching, J., Smallbone, D., \& Athayde, R. (2009). Ethnic diasporas and business competitiveness: Minority-owned enterprises in London. Journal of Ethnic and Migration Studies, 35(4), 689705. https://doi.org/10.1080/13691830902765368.

Kloosterman, R. (2003). Creating opportunities. Policies aimed at increasing openings for immigrant entrepreneurs in the Netherlands. Entrepreneurship and Regional Development, 15(2), 167-181. https://doi.org/10.1080 /0898562032000075159.

Kloosterman, R., Van Leun, J. D., \& Rath, J. (1999). Mixed embeddedness: (In)formal economic activities and immigrant businesses in the Netherlands. International Journal of Urban and Regional Research, 23(2), 252-266. https://doi.org/10.1111/1468-2427.00194.

Kushnirovich, N., \& Heilbrunn, S. (2008). Financial funding of immigrant businesses. Journal of Developmental
Entrepreneurship, 13(2), 167-184. https://doi.org/10.1142 /S1084946708000910.

Li, W., Oberle, A., \& Dymski, G. (2009). Global banking and financial services to immigrants in Canada and the US. Journal of International Migration and Integration, 10(1), 1-29. https://doi.org/10.1007/s12134-008-0089-1.

Li, H., Terjesen, S., \& Umans, T. (2020). Corporate governance in entrepreneurial firms: A systematic review and research agenda. Small Business Economics, 54(1), 43-74. https://doi.org/10.1007/s11187-018-0118-1.

Light, I. H., \& Rosenstein, C. N. (1995). Race, ethnicity, and entrepreneurship in urban America. Piscataway: Transaction Publishers.

Low, M. B., \& MacMillan, I. C. (1988). Entrepreneurship: Past research and future challenges. Journal of Management, 14(2), 139-161. https://doi.org/10.1177 /014920638801400202.

Madhavan, R., \& Iriyama, A. (2009). Understanding global flows of venture capital: Human networks as the "carrier wave" of globalization. Journal of International Business Studies, 40(8), 1241-1259. https://doi.org/10.1057/jibs.2009.6.

Moghaddam, K., Aidov, A., DuVal, C., \& Azarpanah, S. (2017). High-growth entrepreneurial firm funding: A qualitative study of native-born and immigrant entrepreneurs. Venture Capital, 19(1-2), 75-94. https://doi.org/10.1080 /13691066.2016.1256295.

Mongeon, P., \& Paul-Hus, A. (2016). The journal coverage of Web of Science and Scopus: A comparative analysis. Scientometrics, 106(1), 213-228. https://doi.org/10.1007 /s11192-015-1765-5.

Muchineripi, J., Chinyamurindi, W., \& Chimucheka, T. (2019). A narrative analysis of barriers encountered by a sample of immigrant entrepreneurs in the Eastern Cape province of South Africa. The Journal for Transdisciplinary Research in Southern Africa, 15(1), 9. https://doi.org/10.4102/td.v15 i1.556.

Noblit, G. W., \& Hare, R. D. (1988). Meta-ethnography: Synthesizing qualitative studies. 11. sage.

O'reilly, K. (2012). Ethnographic methods. Routledge.

Obstfeld, D., Borgatti, S. P., \& Davis, J. (2014). Brokerage as a process: Decoupling third party action from social network structure. Research in the Sociology of Organizations, 40, 135-159. https://doi.org/10.1108/S0733-558X(2014 0000040007.

Ostrovsky, Y., Picot, G., \& Leung, D. (2019). The financing of immigrant-owned firms in Canada. Small Business Economics, 52(1), 303-317. https://doi.org/10.1007 /s11187-018-0020-x.

Peri, G. (2016). Immigrants, productivity, and labor markets. Journal of Economic Perspectives, 30(4), 3-30. https://doi. org/10.1257/jep.30.4.3.

Petticrew, M., \& Roberts, H. (2008). Systematic reviews in the social sciences: A practical guide. Hoboken: Wiley.

Portes, A., Guarnizo, L. E., \& Landolt, P. (1999). The study of transnationalism: Pitfalls and promise of an emergent research field. Ethnic and Racial Studies, 22(2), 217-237. https://doi.org/10.1080/014198799329468.

Portes, A., Haller, W. J., \& Guarnizo, L. E. (2002). Transnational entrepreneurs: An alternative form of immigrant economic adaptation. American Sociological Review, 278-298. https://doi.org/10.2307/3088896. 
Ram, M., Jones, T., Abbas, T., \& Sanghera, B. (2002). Ethnic minority enterprise in its urban context: South Asian restaurants in Birmingham. International Journal of Urban and Regional Research, 26(1), 24-40. https://doi.org/10.1111 /1468-2427.00361.

Ram, M., Smallbone, D., Deakins, D., \& Jones, T. (2003). Banking on 'break-out': Finance and the development of ethnic minority businesses. Journal of Ethnic and Migration Studies, 29(4), 663-681. https://doi.org/10.1080 $/ 1369183032000123440$.

Rapoport, H., \& Toubal, F. (2019). Special issue of European economic review on "immigration in OECD countries": Introduction. European Economic Review, 118, 270-273. https://doi.org/10.1016/j.euroecorev.2019.06.002.

Rath, J., \& Swagerman, A. (2016). Promoting ethnic entrepreneurship in European cities: Sometimes ambitious, mostly absent, rarely addressing structural features. International Migration Review, 54(1), 152-166. https://doi.org/10.1111/imig.12215.

Rodríguez-Pose, A., \& Von Berlepsch, V. (2014). Social capital and individual happiness in Europe. Journal of Happiness Studies, 15(2), 357-386. https://doi.org/10.1007/s10902013-9426-y.

Rouse, J., \& Jayawarna, D. (2011). Structures of exclusion from enterprise finance. Environment and Planning. C, Government \& Policy, 29(4), 659-676. https://doi. org/10.1068/c0761b.

Ruiz-Vargas, Y. (2000). Small business financing sources between immigrants and natives in Puerto Rico. The Quarterly Review of Economics and Finance, 40(3), 387399. https://doi.org/10.1016/S1062-9769(00)00047-8.

Sandelowski, M., Docherty, S., \& Emden, C. (1997). Qualitative metasynthesis: Issues and techniques. Research in Nursing \& Health, 20(4), 365-371. https://doi.org/10.1002/(SICI)1098240X(199708)20:4<365::AID-NUR9>3.0.CO;2-E.

Sanders, J. M., \& Nee, V. (1996). Immigrant self-employment: The family as social capital and the value of human capital. American Sociological Review, 61(2), 231-249. https://doi. org/10.2307/2096333.

Santamaria-Alvarez, S. M., Sarmiento-González, M. A., \& Arango-Vieira, L. C. (2019). Transnational migrant entrepreneur characteristics and the transnational business nexus: The Colombian case. International Journal of Entrepreneurial Behaviour and Research, 25(5), 1014-1044. https://doi. org/10.1108/IJEBR-02-2018-0092.

Satish, U. (1997). Behavioral complexity: A review. Journal of Applied Social Psychology, 27(23), 2047-2067. https://doi. org/10.1111/j.1559-1816.1997.tb01640.x.

Saxenian, A. (2002). Silicon Valley's new immigrant high-growth entrepreneurs. Economic Development Quarterly, 16(1), 2031. https://doi.org/10.1177/0891242402016001003.

Shepherd, D. A., Souitaris, V., \& Gruber, M. (2020). Creating new ventures: A review and research agenda. Journal of Management, 1557-1211. https://doi.org/10.1177 /0149206319900537.

Shinnar, R. S., Cardon, M. S., Eisenman, M., Zuiker, V. S., \& Lee, M. S. (2009). Immigrant and US-born Mexican-owned businesses: Motivations and management. Journal of Developmental Entrepreneurship, 14(03), 273-295. https://doi.org/10.1142/S1084946709001296.
Smallbone, D., Ram, M., Deakins, D., \& Aldock, R. B. (2003). Access to finance by ethnic minority businesses in the UK. International Small Business Journal: Researching Entrepreneurship, 21(3), 291-314. https://doi.org/10.1177 /02662426030213003.

Streufert, S., \& Driver, M. J. (1967). Impression formation as a measure of the complexity of conceptual structure. Educational and Psychological Measurement, 27(4), 1025-1039.

Streufert, S., \& Satish, U. (1997). Complexity theory: Predictions based on the confluence of science-wide and behavioral theories. Journal of Applied Social Psychology, 27(23), 2096-2116.

Streufert, S., \& Swezey, R. W. (1986). Complexity, managers, and organizations. Cambridge: Academic Press.

Tengeh, R., \& Nkem, L. (2017). Sustaining immigrant entrepreneurship in South Africa: The role of informal financial associations. Sustainability, 9(8), 1396. https://doi. org/10.3390/su9081396.

Torre, A., \& Rallet, A. (2005). Proximity and localization. Regional Studies, 39(1), 47-59. https://doi.org/10.1080 /0034340052000320842.

Torre, A., \& Zuindeau, B. (2009). Proximity economics and environment: Assessment and prospects. Journal of Environmental Planning and Management, 52(1), 1-24. https://doi.org/10.1080/09640560802504613.

Tranfield, D., Denyer, D., \& Smart, P. (2003). Towards a methodology for developing evidence-informed management knowledge by means of systematic review. British Journal of Management, 14(3), 207-222. https://doi.org/10.1111 /1467-8551.00375.

Van Delft, H., Gorter, C., \& Nijkamp, P. (2000). In search of ethnic entrepreneurship opportunities in the city: A comparative policy study. Environment and Planning. C, Government \& Policy, 18(4), 429-451. https://doi. org/10.1068/c9873.

Vinogradov, E. (2008). Immigrant entrepreneurship in Norway (doctoral dissertation). Handelshøgskolen i Bodø.

Welter, F. (2011). Contextualizing entrepreneurship - Conceptual challenges and ways forward. Entrepreneurship Theory and Practice, 35(1), 165-184. https://doi.org/10.1111/j.15406520.2010.00427.x.

Yazdanfar, D., \& Abbasian, S. (2014). Debt financing among native-and immigrant-owned firms: Empirical evidence from Swedish small business at start up stage. World Review of Entrepreneurship, Management and Sustainable Development, 10(4), 422-434. https://doi.org/10.1504 /WREMSD.2014.064950.

Zhang, Z., \& Reay, T. (2018). Managing the Yin and Yang of family capital: A study of Chinese immigrant entrepreneurs. Entrepreneurship and Regional Development, 30(7-8), 722 748. https://doi.org/10.1080/08985626.2018.1457085.

Zhang, J., Wong, P. K., \& Ho, Y. P. (2016). Ethnic enclave and entrepreneurial financing: Asian venture capitalists in Silicon Valley. Strategic Entrepreneurship Journal, 10(3), 318-335. https://doi.org/10.1002/sej.1230.

Publisher's note Springer Nature remains neutral with regard to jurisdictional claims in published maps and institutional affiliations. 